\title{
РОССИЙСКАЯ РЕВОЛЮЦИЯ 1917 ГОДА СКВОЗЬ ПРИЗМУ ДЕМОГРАФИЧЕСКОЙ МОДЕРНИЗАЦИИ
}

\author{
БОРИС МИРОНОВ
}

\begin{abstract}
В позднеимперской России улучшились демографические показатели, несколько повысилась эффективность воспроизводства населения, произошла известная рационализация демографического поведения, гуманизировались внутрисемейные отношения. Но, вероятно, самое главное - у значительной части населения сексуальное, матримониальное и репродуктивное поведение дифференцировалось и получил развитие индивидуальный контроль над рождаемостью, что в демографии рассматривается в качестве критериев первого демографического перехода. Наблюдавшиеся позитивные перемены объяснялись, главным образом тем, что в демографическую револючиию включились около $14 \%$ российских граждан, в основном из числа образованньх и состоятельных людей, проживавших в больших городах, а также жителей западных регионов по вероисповеданию иудеев, католиков и протестантов. Преобладающая часть сельского и городского населения православного, мусульманского, языческого и других вероисповеданий - около 86\% всего населения - были затронуты новыми веяниями поверхностно. Люди, активно и сознательно вовлеченные в демографический переход, изменившиеся психологически, ментально и культурно, проявляли восприимчивость к инновациям также и в социальной, политической, культурной, экономической сферах и являлись наиболее подготовленными и желающими преобразований общественной жизни на буржуазно-демократических основаниях. Их было достаточно для медленной и постепенной всеобъемлющей модернизации страны, но мало для быстрых и глубоких революичонных буржуазно-демократических преобразований. Вследствие этого Революиия 1917 ح. оказалась преждевременной. Политические акушеры поторопились и искусственно ускорили рождение новой России. Новорожденный оказался недоношенным. В результате революичя не смогла решить задачи, которые ставили ее лидеры и организаторы.
\end{abstract}

Ключевые слова: брачность, рождаемость, смертность, эффективность воспроизводства населения, регулирование рождаемости, внебрачные дети, добрачный секс, аборты, контрацепиия, разводы, демографический переход.

Цель статьи состоит в том, чтобы подвести итоги демографической модернизации в позднеимперской России и, основываясь на них, оценить готовность населения к радикальным буржуазно-демократическим преобразованиям общества, на реализацию которых была направлена революция 1917 г.

Анализ основных демографических процессов в имперской России показал, что в XVIII-первой половине XIX века брачность и рождаемость находились почти на предельно высоком уровне, смертность была очень высокой, все показатели заметно варьировались в отдельные годы, не проявляя определенной тенденции ни к росту, ни к понижению функционировала типичная модель традиционного воспроизводства населения (таблица 1).

БОРИС НИКОЛАЕВИч МИРОНОВ (bmironov@mail.wplus.net), САНКТ-ПЕТЕРБУРГСКИЙ ГОСУДАРСТВЕННЫЙ УНИВЕРСИТЕТ, РОССИЯ.

СТАТЬЯ ПОСТУПИЛА В РЕДАКЦИЮ В ИЮЛЕ 2017 Г. 
Таблица 1. Общие коэффициенты брачности, рождаемости, смертности и естественного прироста населения в Европейской России в XVIII-начале XX века, промилле

\begin{tabular}{|c|c|c|c|c|c|c|c|c|}
\hline \multirow[b]{2}{*}{$\begin{array}{l}\text { Демографические } \\
\text { процессы }\end{array}$} & \multirow{2}{*}{$\begin{array}{l}\text { XVIII } \\
\text { век* }\end{array}$} & \multicolumn{7}{|c|}{ Годы } \\
\hline & & $\begin{array}{c}1801- \\
1860 *\end{array}$ & $\begin{array}{c}1861- \\
1870 \\
\end{array}$ & $\begin{array}{l}1871- \\
1880 \\
\end{array}$ & $\begin{array}{l}1881- \\
1890 \\
\end{array}$ & $\begin{array}{c}1891- \\
1900\end{array}$ & $\begin{array}{l}1901- \\
1910 \\
\end{array}$ & $\begin{array}{l}1911- \\
1914 \\
\end{array}$ \\
\hline \multicolumn{9}{|l|}{ Все население: } \\
\hline брачность & 9,9 & 10,2 & 10,3 & 9,5 & 9,1 & 9,0 & 8,4 & 8,0 \\
\hline рождаемость & 51,0 & 50,0 & 50,3 & 50,4 & 50,4 & 49,2 & 46,8 & 43,9 \\
\hline & 37,0 & 36,0 & 36,9 & 36,4 & 35,5 & 34,2 & 30,3 & 27,1 \\
\hline естественный прирост & 14,0 & 14,0 & 13,3 & 14,0 & 14,9 & 15,1 & 16,5 & 16,8 \\
\hline
\end{tabular}

* Только православное население.

Источники: [Движение населения... 1865; Миронов 2014: m.1: 533-534; 1990: 259-260; Новосельский 1916а: 36-37; Сифман 1977; Статистический ежегодник... 1915: 2; Статистический ежегодник... 1918: 193].

Через 10 лет после отмены крепостного права началось устойчивое снижение брачности, через 20 лет (с 1880-х годов) - рождаемости и смертности. Тенденция снижения демографических показателей после Великих реформ 1860-х годов на самом деле была выражена более отчетливо, чем следует из приведенных данных, вследствие улучшения качества демографического учета, которое способствовало увеличению абсолютного значения демографических показателей. Две тенденции - уменьшение абсолютных значений общих коэффициентов и улучшение качества учета (особенно смертности) нивелировали друг друга, и в результате истинная картина несколько искажалась. Вследствие более существенного падения смертности, чем рождаемости, и без того высокие темпы естественного прироста населения стали расти и накануне Первой мировой войны увеличились на 3,5 пункта - с 13,3 до 16,8 промилле, достигнув максимальной величины за весь период империи, но в годы войны, естественно, снизились [Боярский 1975]. Давление на ресурсы усилилось и вместе с общим ростом культуры населения создало предпосылки для перехода от традиционной модели демографического воспроизводства к современной.

\section{БРАК И СЕМЬЯ}

Модель брачности XVIII-первой половины XIX века изменялась благодаря повышению бракоспособного возраста, а в пореформенное время - в силу увеличения числа лиц, не вступающих в брак, роста разводов и сокращения числа повторных браков. Во второй половине XIX века население стало терпимее, чем прежде, относиться к безбрачию, откладыванию брака и разводам; получили некоторое распространение так называемые гражданские браки, т.е. длительное сожительство мужчины и женщины, не зарегистрированное церковью (в дворянско-интеллигентских кругах оно означало «свободную любовь»), и браки, зарегистрированных за границей [Веременко 2007: 49-50].

В течение 1780-1850 гг. модальный возраст невест вырос с 15-16 до 18-20 лет, женихов - с 16-18 до 20-21 года [Миронов 2014: т.1: 564]. В пореформенное время средний 
возраст вступления в брак стабилизировался ${ }^{1}$ [Тольц 1977: 139], но легкая тенденция к повышению все равно существовала: с 1867 по 1910 г. этот возраст увеличился примерно на полгода. Правда, в городах средний возраст брачующихся мужчин понизился вследствие огромной миграции крестьян, по-деревенски рано вступавших в брак (таблица 2).

Таблица 2. Средний возраст вступления в брак городского и сельского населения Европейской России в 1867 и 1910 гг., лет

\begin{tabular}{l|c|c|c|c}
\hline \multirow{2}{*}{ Население } & \multicolumn{2}{|c|}{ Мужчины } & \multicolumn{2}{c}{ Женщины } \\
\cline { 2 - 5 } & 1867 г. & 1910 г. & 1867 г. & 1910 г. \\
\hline Сельское & 24,3 & 24,8 & 21,3 & 21,6 \\
Городское & 29,2 & 27,4 & 23,6 & 23,7 \\
Итого & 24,8 & 25,2 & 21,5 & 21,9 \\
\hline
\end{tabular}

Источники: [Движение населения... 1872: 40-407, 412-415; Движение населения... 1916: 88-89].

За относительной стабильностью среднего возраста скрывались изменения возрастной структуры брачующихся: доля вступавших в брак ранее 21 года и после 30 лет уменьшилась, а в интервале 21-30 лет увеличилась (таблица 3).

Таблица 3. Распределение вступивших в брак по возрастным группам в Европейской России в 1867-1910 гг., \%

\begin{tabular}{l|c|c|c|c|c|c}
\hline \multirow{2}{*}{ Годы } & \multicolumn{7}{c}{ Возраст женихов, лет } \\
\cline { 2 - 7 } & 20 и моложе & $21-25$ & $25-30$ & $30-40$ & $40-50$ & 51 и выше \\
\hline $1867-1871$ & 37,8 & 31,0 & 10,9 & 12,6 & 5,9 & 1,8 \\
$1872-1876$ & 37,7 & 30,7 & 13,0 & 11,5 & 5,2 & 1,9 \\
$1877-1881$ & 37,2 & 29,7 & 15,9 & 10,5 & 4,6 & 2,1 \\
$1890-1894$ & 31,2 & 33,9 & 19,1 & 9,8 & 4,1 & 1,9 \\
$1895-1898$ & 30,8 & 35,6 & 19,1 & 9,1 & 3,5 & 1,8 \\
1910 г. & 30,8 & 36,2 & 18,8 & 8,9 & 3,5 & 1,8 \\
& & & Возраст невест, лет & & \\
$1867-1871$ & 57,3 & 26,3 & 7,1 & 6,7 & 2,2 & 0,4 \\
$1872-1876$ & 57,7 & 26,8 & 7,0 & 5,9 & 2,2 & 0,4 \\
$1877-1881$ & 59,0 & 27,0 & 6,7 & 5,2 & 2,0 & 0,1 \\
$1890-1894$ & 55,3 & 30,4 & 7,3 & 4,8 & 1,8 & 0,4 \\
$1895-1898$ & 54,7 & 31,7 & 7,1 & 4,5 & 1,6 & 0,4 \\
1910 г. & 54,5 & 31,0 & 7,3 & 4,7 & 1,9 & 0,6 \\
\hline
\end{tabular}

Источники: [Рашин 1956: 174-175; Сборник сведений по России... 1887: 36-37].

Доля лиц, воздерживавшихся от брака, выросла, но также незначительно. До середины XIX века вне брака оставались только лица с серьезной инвалидностью (около $3 \%$ населения). На рубеже XIX-XX веков к моменту окончания фертильного возраста доля лиц, никогда не состоявших в браке, повысилась до 4\% в деревне и до $11 \%$ в городе (таблица 4).

Одновременно возросла доля лиц, воздерживавшихся от вступления в повторный брак после овдовения, до примерно $15 \%$ в городе и 9\% в деревне. В результате понизилась средняя длительность пребывания в браке - примерно до 20 лет у горожан и до 25 лет у крестьян [Вишневский 1977: 114-120; Тольц 1977: 138-153]. Изменения брачной модели

\footnotetext{
${ }^{1}$ Средний возраст всех русских невест, вступавших в первый брак, в 1867-1910 гг. равнялся 21,4 года, женихов
} $-24,2$ года. 
начались в городе в первой половине XIX века и во второй половине XIX века распространились на деревню, что отчетливо просматривается по данным таблицы 5. В 1910 г. изменения возрастной структуры браков в наибольшей степени затронули крупные города, затем малые города, наконец, сельскую местность.

Таблица 4. Доля вдовых и лиц, никогда не состоявших в браке, среди городского и сельского населения Европейской России в 1897 г.

\begin{tabular}{|c|c|c|c|c|c|c|c|c|}
\hline \multirow{3}{*}{ Возраст, лет } & \multicolumn{4}{|c|}{ Никогда не состояли в браке, \% } & \multicolumn{4}{|c|}{ Доля вдовых, \% } \\
\hline & \multicolumn{2}{|c|}{ мужчины } & \multicolumn{2}{|c|}{ женщины } & \multicolumn{2}{|c|}{ мужчины } & \multicolumn{2}{|c|}{ женщины } \\
\hline & город & село & город & село & город & село & город & село \\
\hline $15-19$ & 98 & 95 & 91 & 87 & - & - & - & - \\
\hline $20-29$ & 60 & 35 & 38 & 20 & 1 & 1 & 4 & 1 \\
\hline $30-39$ & 18 & 6 & 16 & 6 & 2 & 1 & 12 & 5 \\
\hline $40-49$ & 11 & 3 & 12 & 4 & 5 & 4 & 26 & 14 \\
\hline $50-59$ & - & - & - & - & 11 & 11 & 45 & 29 \\
\hline 15 и старше* & 42 & 28 & 30 & 21 & 4 & 6 & 18 & 13 \\
\hline
\end{tabular}

Источники: [Тольи 1977: 140, 149; Новосельский 1916а: 28].

Таблица 5. Распределение вступивших в брак по возрастным группам в городах и сельских местностях Европейской России в 1910 г.

\begin{tabular}{|c|c|c|c|c|c|c|}
\hline \multirow{2}{*}{ Место заключения брака } & \multicolumn{6}{|c|}{ Возраст, лет } \\
\hline & $20-$ & $21-25$ & $26-30$ & $31-40$ & $41-50$ & $51+$ \\
\hline \multicolumn{7}{|c|}{ Мужчины } \\
\hline В главных городах & 11,5 & 36,4 & 29,0 & 16,0 & 4,8 & 2,3 \\
\hline В прочих городах & 14,4 & 40,1 & 27,1 & 12,1 & 4,0 & 2,3 \\
\hline В сельских местностях & 33,3 & 36,0 & 17,5 & 8,1 & 3,4 & 1,7 \\
\hline Итого & 30,8 & 36,2 & 18,8 & 8,9 & 3,5 & 1,8 \\
\hline \multicolumn{7}{|c|}{ Женщины } \\
\hline В главных городах & 35,5 & 35,1 & 14,3 & 10,6 & 3,7 & 0,8 \\
\hline В прочих городах & 43,0 & 37,4 & 10,8 & 6,0 & 2,1 & 0,7 \\
\hline В сельских местностях & 56,7 & 30,2 & 6,7 & 4,1 & 1,7 & 0,6 \\
\hline Итого & 54,5 & 31,0 & 7,3 & 4,7 & 1,9 & 0,6 \\
\hline
\end{tabular}

Источник: [Движение населения... 1916: 88-89].

Инициаторами изменений в брачной модели выступали образованные слои населения, в первую очередь дворянство, в большей степени концентрировавшиеся в городах. Данные о семейном состоянии важнейших сословий по пяти губерниям (Гродненской, Калужской, Пермской, Симбирской и Ярославской) в 1850-е годы и 1897 г. это хорошо отражают (таблица 6).

Поскольку именно в столице империи, Петербурге, концентрировались образованные люди и находилось много иностранцев, изменения в брачной модели там были особенно заметны. Уже в 1864 г. в столице доля холостых и девиц достигала 35\%. Средний возраст вступления в первый брак составлял у мужчин 30,5 года, у женщин - 25,5 года. Сезонность браков существенно сгладилась [Санкт-Петербург 1868: т.1:104, 134, 138, 144]. В начале XX века появились первые сотни разведенных, которые во всем населении города составляли 0,18\% [Статистический ежегодник С.-Петербурга... 1905: 17], тысячи гражданских браков. Попечительские обследования 1915-1916 гг. среди семей столичных нижних воинских чинов обнаружили около 10\% внебрачных семей, что стало сенсацией [Булгакова 2008; 2009]. Кончено, это было специфическое военное время, когда в 
Петрограде сконцентрировалось огромное число военных. Однако столь широкого распространения незарегистрированные гражданские браки на неподготовленной почве вряд ли могли достигнуть.

Таблица 6. Семейное состояние населения Европейской России в бракоспособном возрасте по сословиям в 1850-е годы и в 1897 г., \%

\begin{tabular}{|c|c|c|c|c|c|c|c|c|}
\hline \multirow{2}{*}{ Семейное состояние } & \multicolumn{2}{|c|}{ Купцы, мещане } & \multicolumn{2}{|c|}{ Крестьяне } & \multicolumn{2}{|c|}{ Дворяне } & \multicolumn{2}{|c|}{ Духовенство } \\
\hline & муж. & жен. & муж. & жен. & муж. & жен. & муж. & жен. \\
\hline \multicolumn{9}{|c|}{ 1850-е годы, по пяти губерниям } \\
\hline Не достигшие брачного возраста & 42 & 33 & 44 & 40 & - & - & 50 & 39 \\
\hline Холостые и девицы & 15 & 21 & 7 & 12 & - & - & 7 & 13 \\
\hline Состоявшие в браке & 38 & 32 & 44 & 40 & - & - & 37 & 35 \\
\hline Вдовые & 5 & 14 & 5 & 8 & - & - & 6 & 13 \\
\hline \multicolumn{9}{|c|}{1897 г., по пяти губерниям } \\
\hline Не достигшие брачного возраста & 34 & 33 & 47 & 41 & - & - & - & - \\
\hline Холостые и девицы & 23 & 19 & 8 & 12 & - & - & - & - \\
\hline Состоявшие в браке & 40 & 34 & 41 & 38 & 一 & - & 一 & - \\
\hline Вдовые & 3 & 14 & 4 & 9 & - & - & - & - \\
\hline Разведенные & 0,1 & 0,1 & 0,07 & 0,05 & - & - & - & - \\
\hline \multicolumn{9}{|c|}{1897 г., Европейская Россия } \\
\hline Не достигшие брачного возраста & 43 & 39 & 45 & 40 & 36 & 30 & 40 & 32 \\
\hline Холостые и девицы & 17 & 16 & 11 & 12 & 26 & 24 & 19 & 27 \\
\hline Состоявшие в браке & 37 & 35 & 40 & 40 & 34 & 32 & 34 & 29 \\
\hline Вдовые & 3 & 10 & 4 & 8 & 4 & 14 & 7 & 12 \\
\hline Разведенные & 0,1 & 0,3 & 0,01 & 0,05 & 0,2 & 0,2 & 0,04 & 0,04 \\
\hline
\end{tabular}

Источники: [Луканин 1878: 206; Трубников 1858: 417; О составе... 1861: 90; Бобровский 1863: 536540; Попроикий 1864: 330; Общий свод... 1905: т.2: 198-207, 216-219, 224-225].

Источниками перемен в брачной модели служили изменения не только в объективных условиях жизни, но и в отношении населения к браку. Идея брака на всю жизнь стала подвергаться эрозии, появилась возможность замены партнера через развод в случае, если он злоупотреблял властью, не хранил верность, надолго уезжал, не исполнял супружеские обязанности. В наименьшей степени эти перемены также затронули семьи крестьян и городских низов, т.е. около 90\% населения страны.

Таблица 7. Число браков в 1800-1960-е годы в России и ряде других стран, на 1000 человек населения

\begin{tabular}{|c|c|c|c|c|c|c|c|c|}
\hline \multirow{2}{*}{ Страна } & \multicolumn{8}{|c|}{ Годы } \\
\hline & $1800-\mathrm{e}$ & $1850-\mathrm{e}$ & $1880-\mathrm{e}$ & $1900-\mathrm{e}$ & 1920-e & $1930-\mathrm{e}$ & 1950-e & 1960-e \\
\hline Россия & 9,9 & 10,3 & 9,2 & 8,5 & 9,9 & 6,3 & 11,9 & 10,8 \\
\hline Австро-Венгрия* & 8,1 & 8,0 & 7,8 & 7,8 & 9,2 & 8,6 & 8,3 & 8,0 \\
\hline Англия & - & 8,5 & 7,5 & 7,0 & 8,0 & 8,5 & 7,9 & 7,8 \\
\hline США & - & 9,6 & 8,7 & 10,5 & 10,5 & 9,8 & 9,5 & 9,3 \\
\hline Германия & 8,2 & 8,0 & 7,4 & 8,1 & 9,7 & 9,4 & 9,3 & 8,5 \\
\hline Франция & 7,6 & 8,0 & 7,4 & 7,8 & 9,7 & 7,1 & 7,3 & 7,1 \\
\hline Япония & - & - & 8,2 & 8,8 & 8,5 & 8,0 & 8,4 & 9,7 \\
\hline
\end{tabular}

Источник: [Миронов 2015: m.3: 753-756].

Примечание: *-C 1918 г. Австрия.

Изменения брачной модели привели к снижению общего уровня брачности в стране. И все же Россия по уровню брачности вплоть до начала XX века занимала первое место среди развитых европейских стран и США. Только в 1900-е годы на первое место вышли 
США благодаря огромной эмиграции взрослого населения из Европы и сохранили лидерство в последующие 40 лет (таблица 7).

Российская модель брачности XVIII-первой половины XIX века отличалась от западноевропейской, для которой были характерны поздние браки (возраст невест превышал 25 лет, женихов - 27 лет) и значительная доля лиц, никогда не состоявших в браке (минимум 9-10\% и в ряде случаев более 15\%). Сдвиги пореформенного периода несколько уменьшили различия, но существенный разрыв в начале XX века все равно оставался (таблицы 8, 9).

Таблица 8. Доля мужчин и женщин, никогда не состоявших в браке, в некоторых странах Европы на рубеже XIX-XX веков, \%

\begin{tabular}{l|r|r|rr}
\hline \multirow{2}{*}{ Страны } & \multicolumn{4}{c}{ Возраст, лет } \\
\cline { 2 - 5 } & \multicolumn{2}{c}{ женщины } & \multicolumn{3}{c}{ мужчины } \\
\cline { 2 - 5 } Ирландия & $20-24$ & $45-49$ & $20-24$ & $45-49$ \\
Швеция & 86 & 17 & 96 & 20 \\
Великобритания & 80 & 19 & 92 & 13 \\
Германия & 73 & 15 & 83 & 12 \\
Финляндия & 71 & 10 & 91 & 9 \\
Италия & 68 & 15 & 84 & 14 \\
Франция & 60 & 11 & 86 & 11 \\
Испания & 58 & 12 & 90 & 11 \\
Греция & 81 & 34 & 55 & 10 \\
Европейская Россия** & 44 & 4 & 92 & 9 \\
Болгария & 35 & 5 & 54 & 4 \\
Румыния & 24 & 1 & 58 & 3 \\
Сербия & 20 & 3 & 67 & 5 \\
\hline
\end{tabular}

* Возрастные группы для Испании: 21-25 лет; 46-50 лет. ** По расчету М. Тольцуа.

Источники: [Hajnal 1965: 102-103; Тольи 1977: 139].

Таблица 9. Доля лиц в возрасте 45-49 лет, никогда не состоявших в браке, в некоторых странах мира на рубеже XIX-XX веков, \%

\begin{tabular}{l|c|c|l|r|r}
\hline Страна, год & Женщины & Мужчины & Страна, год & Женщины & Мужчины \\
\hline Швеция, 1900 & 19,0 & 13,0 & Австралия, 1901 & 9,3 & 22,4 \\
Бельгия, 1900 & 17,1 & 16,1 & США, 1900 & 8,6 & 12,0 \\
Швейцария, 1900 & 17,0 & 16,0 & Чехия, 1910 & 8,5 & 6,2 \\
Нидерланды, 1900 & 14,0 & 13,0 & Польша, 1900 & 7,8 & 6,1 \\
Англия и Уэльс, 1901 & 13,4 & 11,0 & Европейская Россия, 1897 & 5,0 & 4,0 \\
Австрия, 1900 & 13,0 & 11,0 & Греция, 1907 & 4,0 & 9,0 \\
Канада, 1911 & 12,0 & 15,1 & Венгрия, 1900 & 4,0 & 5,0 \\
Франция, 1901-1905 & 11,2 & 10,4 & Румыния, 1899 & 3,0 & 5,0 \\
Италия, 1901 & 10,9 & 10,9 & Япония, 1920 & 1,9 & 2,3 \\
Испания, 1900 & 10,2 & 6,4 & Болгария, 1900 & 1,0 & 3,0 \\
Германия, 1900 & 10,1 & 8,2 & Сербия, 1900 & 1,0 & 3,0 \\
\hline
\end{tabular}

Источник: [Patterns of first marriage... 1990: 7-18].

Как в деревне, так и в городе изменялась семейная организация населения. Имеющиеся данные о семейной структуре крестьян говорят о том, что в течение XVIпервой половины XIX века малая и составная семья мирно сосуществовали. Их соотношение изменялось, что объяснялось изменениями налоговой системы и благосостоянием населения, экономической конъюнктурой, социальными и 
хозяйственными кризисами, политикой помещиков в отношении своих крестьян, а также колонизацией. До середины XIX века составная семья нередко перерастала в большую семью и в редчайших случаях в семью типа задруги, объединявшую много брачных пар и до 100 человек. Даже в 1850-е годы в каждой губернии встречалось много больших семей, насчитывавших 20-30 и более человек. Их доля была не велика $(0,3-1,6 \%)$, однако их насчитывались тысячи. Все это свидетельствует о том, что большая семья еще не стала атавизмом даже в середине XIX века. В пореформенное время малая семья в деревне заметно и во всех регионах усилила свои позиции сравнительно с серединой XIX века и к 1897 г. в целом у крестьянства Европейской России она стала численно слегка преобладать. Существенная роль в сохранении традиции составной семьи принадлежала социальноэкономическим факторам: передельной общине, крепостному праву, правовым ограничениям для развития частной собственности на землю, отсутствию единонаследия, обеспеченности землей и угодьями, форме ренты, особенностям климата, характеру хозяйственной деятельности, степени развития рынка труда и другим.

Горожане в период империи отдавали предпочтение малой семье. Однако до середины XIX века более половины городского населения на протяжении определенного периода своей жизни проживало в рамках составной семьи. В разных социальных группах и в разных регионах процесс нуклеаризации происходил противоречиво. О победе малой семьи в городе можно говорить применительно к началу XX века. В изживании архаических форм семейной организации город обгонял деревню примерно на 50 лет, т.е. на два поколения: типология семей, наблюдавшаяся в городах в середине XIX века, пришла в деревню лишь на рубеже XIX-XX веков.

Процесс полной и окончательной нуклеаризации семьи завершился только в XX веке. Доля составных семей в семейной структуре в 1994 г. составила лишь 3,6\%. К тому же они, как правило, сохранялись не из-за склонности к совместной жизни некоторой части детей и родителей, а в силу необходимости - недоступности отдельного жилья для молодежи.

В пореформенное время у всех сословий наметились изменения и во внутрисемейных отношениях. Дворянство и интеллигенция стали пионерами перехода от патриархальноавторитарных к эгалитарным семьям и от патриархальных к демократическим отношениям в семье в последней трети XIX-начале XX века. Однако ни в среде крестьянства, ни в среде городских низов патриархально-авторитарная основа внутрисемейных отношений не была серьезно подорвана и в основных чертах сохранилась к 1917 г. Об этом свидетельствует тот факт, что даже в российской деревне 1920-х годов традиционные взгляды на семью и женщину оставались очень прочными [Феноменов 1925: 98-106; Яковлев 1923; 1924; Bridger 1992: 271-293; Farnsworth 1992: 167-188]. Прогресс выражался в смягчении насилия над слабыми в семье и в установлении известного контроля со стороны общества и закона за соблюдением интересов женщин и детей. Авторитарность внутри семьи была в большей или меньшей степени поставлена в рамки закона. До середины XIX века в брак вступали, как правило, по прямому указанию родителей, с помощью сватовства, через помолвку и свадьбу с учетом семейных интересов. В последней трети XIX-начале XX века молодежь стала участвовать в выборе супруга, руководствуясь склонностями и другими личными соображениями. Одновременно цели контактов расширились: не только поиск супруга, как 
было прежде, а также развлечение, эмоциональный контакт, получение удовольствия и др. Сильные пережитки крепостничества, стойкая патриархальность внутри семьи, слабое развитие феминистского движения в России помешали завершению этого процесса даже среди элиты российского общества, если иметь в виду основную массу семей привилегированных слоев.

Перемены в семейном укладе жизни в позднеимперской России многим исследователям в прошлом и настоящем кажутся кризисом института семьи и заодно признаком общего социального кризиса российского общества. С этим трудно согласиться. Невозможно считать кризисом такие прогрессивные изменения, как снижение брачности и рождаемости с запредельной высоты до «нормального» уровня, повышение возраста вступления в брак, нуклеаризация, демократизация и гуманизация внутрисемейных отношений, повышение статуса женщин и детей, рост количества разводов и раздельного проживания супругов, увеличение числа гражданских браков и конфликтов супругов и «отцов и детей», расширение применения контрацепции и абортов, облегчение узаконения внебрачных и усыновления законных детей, установление контроля со стороны общества и суда за соблюдением интересов женщин и детей. Например, 3791 расторжение на 1053 тыс. заключенных в 1913 г. браков [Статистический ежегодник... 1916: 2] нельзя считать кризисом семьи, даже если число разводов возросло в 46 раз по сравнению с 1861 г. Перечисленные перемены на самом деле свидетельствовали не о кризисе института семьи, а о его развитии в направлении модерна. Можно только сожалеть, что эти изменения затронули главным образом образованную часть общества и зашли не слишком далеко. Да и сами эти изменения обусловливались модерновыми процессами: секуляризацией, демократизацией, индустриализацией, урбанизацией, ростом грамотности и распространением либеральных идей в обществе. Благодаря быстрому развитию средств массовой информации новые семейные практики становились известны общественности и становились предметом острых публичных споров между людьми, придерживавшимися разных идеологических ориентаций [Никологорский 2012: 28-32]. Хотелось бы напомнить также, что модернизация всегда, везде и во всех сферах жизни происходит болезненно.

\section{РОЖДАЕМОСТЬ И СМЕРТНОСТЬ}

Снижение рождаемости началось во второй трети XIX века у дворянства, чиновничества, высшей страты городского населения, а также у крепостного помещичьего крестьянства. Во второй половине XIX века оно постепенно охватило все остальные группы населения и все регионы Европейской России. В результате в 1841-1920 гг. итоговая рождаемость в когортах матерей сравнительно с рождаемостью в когортах дочерей уменьшилась согласно ориентировочной оценке С.В. Захарова в 2,3 раза (таблица 10).

Как и в случае с брачностью, снижение рождаемости происходило под влиянием экономических, культурных и психологических факторов, среди которых следует особо выделить увеличение плотности населения и соответствующее уменьшение природных ресурсов на душу населения в деревне во второй трети XIX века, а также изменение культурных стандартов у образованных классов общества и городских сословий. Важно подчеркнуть, что падение рождаемости происходило не стихийно, а сознательно в 
результате снижения брачности и начавшегося со второй трети XIX века регулирования рождаемости (подробнее об этом ниже). В России оно началось с более высокого уровня и позднее, чем в большинстве развитых стран. Запаздывание по сравнению с большинством европейских стран составляет, в среднем, 30-40 лет, а по сравнению с Францией - почти столетие. Однако со временем различия уменьшались (таблица 11).

Таблица 10. Итоговая рождаемость реальных поколений в России в 1841-1920 гг.

\begin{tabular}{c|c|c|c|c}
\hline \multicolumn{2}{c|}{ Годы рождения } & \multicolumn{2}{|c|}{ Итоговая рождаемость } & $\begin{array}{c}\text { Отношение рождаемости в } \\
\text { когортах «дочерей» и в } \\
\text { когортах «матерей» }\end{array}$ \\
\hline $\begin{array}{c}\text { кматерей» } \\
\text { «могорта } \\
1841-1845\end{array}$ & $\begin{array}{c}\text { когорта } \\
\text { «матерей» }\end{array}$ & $\begin{array}{c}\text { когорта } \\
\text { «дочерей» }\end{array}$ & 1,017 \\
$1846-1850$ & $1871-1875$ & 6,84 & 6,96 & 0,993 \\
$1851-1855$ & $1876-1880$ & 6,9 & 6,85 & 0,876 \\
$1856-1860$ & $1886-1885$ & 7,08 & 6,2 & 0,772 \\
$1861-1865$ & $1891-1895$ & 7,11 & 5,49 & 0,772 \\
$1866-1870$ & $1896-1900$ & 7,12 & 5,5 & 0,726 \\
$1871-1875$ & $1901-1905$ & 7,2 & 5,23 & 0,659 \\
$1876-1880$ & $1906-1910$ & 6,96 & 4,59 & 0,534 \\
$1881-1885$ & $1911-1915$ & 6,85 & 3,66 & 0,455 \\
$1886-1890$ & $1916-1920$ & 6,2 & 2,82 & 0,448 \\
\hline
\end{tabular}

Источники: [Захаров 2002: 19-26; 2003: 3-12].

Таблица 11. Коэффициент общей рождаемости в 1800-1960-е годы в России и ряде других стран, на 1000 человек населения

\begin{tabular}{l|r|r|r|r|r|r|r|r}
\hline \multirow{2}{*}{ Страна } & \multicolumn{8}{c}{ Годы } \\
\cline { 2 - 9 } & $1800-\mathrm{e}$ & $1850-\mathrm{e}$ & $1880-\mathrm{e}$ & $1900-\mathrm{e}$ & $1920-\mathrm{e}$ & $1930-\mathrm{e}$ & $1950-\mathrm{e}$ & $1960-\mathrm{e}$ \\
\hline Россия & 50,3 & 51,5 & 50,3 & 47,2 & 44,0 & 34,6 & 25,9 & 20,0 \\
Австро-Венгрия* & 39,5 & 37,8 & 38,0 & 34,9 & 20,5 & 14,9 & 15,9 & 17,9 \\
Англия & - & 34,1 & 32,9 & 28,7 & 19,3 & 15,1 & 15,7 & 17,6 \\
США & 57,7 & 45,3 & 39,8 & 31,2 & 25,0 & 19,2 & 24,8 & 20,3 \\
Германия & 38,3 & 35,4 & 37,0 & 33,6 & 21,1 & 17,8 & 16,1 & 17,3 \\
Франция & 32,0 & 26,4 & 24,2 & 20,7 & 19,1 & 15,9 & 18,0 & 17,5 \\
Япония & - & - & 26,9 & 32,1 & 34,1 & 30,2 & 19,8 & 17,7 \\
\hline
\end{tabular}

* С 1918 г. Австрия.

Источник: [Миронов 2015: m. 3: 753-756].

На протяжении XVIII - начала XX века смертность среди православного населения России находилась на очень высоком уровне как в городе, так и в деревне, как среди простого народа, так и среди привилегированной части общества. B XVIII веке общий коэффициент смертности в городе колебался между 40 и 60, в деревне - между 30 и 40 на 1000 человек населения. В первой половине XIX века колебания смертности по годам несколько сгладились, но средний уровень оставался, как и прежде, высоким: в городе около 49, в деревне 35 на 1000 [Миронов 1990: таблица 2]. С 1860-х годов смертность начала постепенно снижаться: общий коэффициент смертности с 1851-1859 по 1909-1913 гг. в городе понизился с 53 до 27, в деревне - с 39 до 32 на 1000 [Новосельский 1916а: 45-46; 1916b: 180-187]. Снижение смертности было повсеместным, но в городе оно проходило интенсивнее, чем в деревне, в крупных городах значительнее, чем в малых, среди привилегированных слоев быстрее, чем среди низших классов населения, в западных губерниях началось раньше, чем в центральных и восточных. Общая смертность снижалась в основном благодаря падению младенческой смертности [Авдеев 2008]. 
Уровень той и другой в России был намного выше, чем в наиболее развитых странах: в 1900-е годы по этим показателям Россия отставала на столетие. По общей смертности выравнивание произошло в 1950-е годы (таблица 12), а по младенческой смертности различия уменьшались, но паритет не достигнут до настоящего времени (таблица 13).

Таблица 12. Общий коэффициент смертности в 1800-1960-е годы в России и ряде других стран, на 1000 человек населения

\begin{tabular}{l|c|c|c|c|c|c|rr}
\hline \multirow{2}{*}{ Страна } & \multicolumn{7}{c}{ Годы } \\
\cline { 2 - 9 } & $1800-\mathrm{e}$ & $1850-\mathrm{e}$ & $1880-\mathrm{e}$ & $1900-\mathrm{e}$ & $1920-\mathrm{e}$ & $1930-\mathrm{e}$ & $1950-\mathrm{e}$ & 1960 -е \\
\hline Россия & 36,8 & 39,8 & 35,4 & 30,2 & 22,9 & 18,0 & 8,5 & 7,4 \\
Австро-Венгрия* & 28,2 & 32,1 & 29,5 & 23,7 & 15,7 & 13,7 & 12,4 & 12,8 \\
Англия & - & 22,1 & 19,2 & 16,9 & 12,2 & 12,0 & 11,6 & 11,7 \\
США & - & 19,5 & 18,4 & 15,8 & 11,9 & 11,0 & 9,5 & 9,5 \\
Германия & 25,2 & 26,6 & 25,3 & 19,3 & 12,9 & 11,4 & 11,0 & 11,6 \\
Франция & 28,0 & 23,9 & 22,1 & 19,8 & 17,2 & 15,5 & 12,2 & 11,1 \\
Япония & - & - & 19,6 & 20,9 & 20,6 & 17,6 & 8,2 & 7,0 \\
\hline
\end{tabular}

* C 1918 г. Австрия.

Источник: [Миронов 2015: т.3: 753-756].

Таблица 13. Коэффициент младенческой смертности в 1800-1960-е годы в России и ряде других стран, на 1000 родившихся

\begin{tabular}{l|c|c|c|r|r|r|r|r}
\hline \multirow{2}{*}{ Страна } & \multicolumn{8}{c}{ Годы } \\
\cline { 2 - 8 } & $1800-\mathrm{e}$ & $1850-\mathrm{e}$ & $1880-\mathrm{e}$ & $1900-\mathrm{e}$ & $1920-\mathrm{e}$ & $1930-\mathrm{e}$ & $1950-\mathrm{e}$ & $1960-\mathrm{e}$ \\
\hline Россия & - & 272,0 & 268,0 & 250,0 & 206,0 & 182,0 & 60,9 & 29,0 \\
Австро-Венгрия* & 188,0 & 250,0 & 249,0 & 213,0 & 129,0 & 93,6 & 49,0 & 29,7 \\
Англия & - & 155,0 & 142,0 & 132,0 & 73,8 & 59,0 & 26,0 & 19,8 \\
США & - & 127,0 & 160,0 & 96,5 & 73,1 & 56,8 & 27,3 & 24,0 \\
Германия & 294,0 & 172,0 & 167,0 & 193,0 & 112,0 & 65,1 & 44,0 & 26,4 \\
Франция & 185,0 & 172,0 & 167,0 & 137,0 & 101,0 & 75,0 & 40,0 & 23,3 \\
Япония & - & - & - & - & 148,0 & 114,0 & 42,0 & 19,4 \\
\hline
\end{tabular}

* С 1918 г. Австрия.

Источник: [Миронов 2015: т.3: 753-756].

Снижение смертности в 60-х годах XIX века происходило благодаря повышению жизненного уровня населения и улучшению его питания [Миронов 2012: 697-701], а также благодаря росту культурного уровня населения и расширению бесплатной медицинской помощи. За 1850-1913 гг. грамотность населения в возрасте старше 9 лет выросла с 15 до 40\% [Миронов 1991: 82]. В 1837 г. в России насчитывалось 6,8 тыс. врачей (без дантистов), в 1846 г. - 8,7 тыс., в 1880 г. - 13,5 тыс., в 1913 г. - 28,1 тыс. [Ханыков 1851: 31-32; Миронов 1991: 144]. Число врачебных участков, где крестьянам оказывалась бесплатная медицинская помощь, за 1870-1913 гг. увеличилось с 530 до 2970 или в 5,6 раза [Новосельский 1916b: 184]. Но Россия пока еще сильно отставала в этом отношении от передовых европейских стран (таблица 14).

Параллельно с падением смертности росла средняя продолжительность предстоящей жизни. В 1838-1850 гг. у новорожденных мальчиков православного вероисповедания она составляла примерно 25 лет, у девочек - 27 лет, в 1904-1913 гг. соответственно 32,4 и 34,5 года [Воспроизводство населения... 1983: 61]. В 1900-е годы от 
ведущих стран Россия отстала примерно на 100 лет; в 1950-е годы отставание удалось преодолеть (таблица 15).

Таблица 14. Характеристики доступности медицинской помощи в России и некоторых европейских странах в конце XIX века

\begin{tabular}{l|r|c|r|r|r}
\hline \multirow{2}{*}{ Страна } & \multicolumn{2}{|c|}{ Число врачей } & \multicolumn{2}{c}{ На одного врача приходится } \\
\cline { 2 - 6 } & всего & $\begin{array}{c}\text { на 1 млн } \\
\text { населения }\end{array}$ & человек & $\begin{array}{r}\text { территории, } \\
\text { км }^{2}\end{array}$ & $\begin{array}{c}\text { радиус } \\
\text { действия, км }\end{array}$ \\
\hline Европейская Россия & 13475 & 155 & 6450 & 1352 & 21 \\
Норвегия & 502 & 275 & 3630 & 641 & 14 \\
Австрия & 10690 & 275 & 3630 & 28 & 3 \\
Италия & 8580 & 280 & 3570 & 35 & 3 \\
Испания & 5200 & 305 & 3280 & 99 & 6 \\
Германия & 16270 & 355 & 2820 & 33 & 3 \\
Франция & 14380 & 380 & 2630 & 37 & 2 \\
Бельгия & 2160 & 390 & 2540 & 16 & 2 \\
Нидерланды & 1860 & 410 & 2440 & 18 & 2 \\
Великобритания & 22105 & 578 & 1730 & 10 & \multicolumn{3}{c}{} \\
\hline
\end{tabular}

Источник: [Хлопин, Эрисман 1899: 225].

Таблица 15. Средняя продолжительность предстоящей жизни при рождении в 18001960-е годы в России и ряде других стран, лет

\begin{tabular}{l|r|r|r|r|r|r|r|c}
\hline \multirow{2}{*}{ Страна } & \multicolumn{10}{c}{ Годы } \\
\cline { 2 - 9 } & $1800-\mathrm{e}$ & $1850-\mathrm{e}$ & $1880-\mathrm{e}$ & $1900-\mathrm{e}$ & $1920-\mathrm{e}$ & $1930-\mathrm{e}$ & $1950-\mathrm{e}$ & $1960-\mathrm{e}$ \\
\hline Россия & - & 25,8 & 30,0 & 33,5 & 44,4 & 46,9 & 68,1 & 69,1 \\
Австро-Венгрия* & - & - & - & 40,1 & - & 57,0 & 64,5 & 69,8 \\
Англия & - & 42,4 & 45,5 & 53,4 & 57,6 & 60,8 & 70,3 & 71,0 \\
США & - & 41,0 & 43,5 & 50,6 & 58,7 & 63,7 & 69,9 & 71,0 \\
Германия & - & - & 46,6 & 49,1 & 57,4 & 61,4 & 66,5 & 70,5 \\
Франция & 39,6 & 39,8 & 47,0 & 50,5 & 54,2 & 58,8 & 68,1 & 71,4 \\
Япония & - & - & 43,6 & 44,5 & 44,2 & 48,3 & 66,2 & 71,7 \\
\hline
\end{tabular}

* С 1918 г. Австрия.

Источник: [Миронов 2015: т.3: 753-756].

В 1896-1897 гг. общая рождаемость населения России составляла 54\% от физиологического максимума (за который принимается брачная рождаемость гуттеритов членов американской религиозной секты, отличающихся хорошим здоровьем и полным отсутствием внутрисемейного регулирования), брачная рождаемость - 76\% [Вишневский 1977: 131].

\section{ИННОВАЦИИ И ДЕВИАЦИИ В ДЕМОГРАФИЧЕСКОМ ПОВЕДЕНИИ}

Девиации в демографическом поведении можно рассматривать как инновации на индивидуальном уровне, направленные против традиционных установок и господствующих практик. Масштаб девиаций показывает число людей, готовых и склонных к изменению моделей традиционного поведения. К ним можно отнести добрачный секс, внебрачные связи и детей, разводы, самоубийства, аборты и детоубийства, контрацепцию. 


\section{Добрачный и внебрачный секс}

Для всего исследуемого времени стремление предотвратить беременность или избавиться от нежеланного ребенка было свойственно тем женщинам, которые вступали во внебрачные половые отношения, так как родить вне брака считалось большим позором и для женщины, и для ее родственников. Очень часто матерями внебрачных детей являлись солдатки - женщины, чьи мужья ушли в армию2 [Щербинин 2004: 95-132]. Сколько же насчитывалось таких женщин? На этот вопрос приблизительный ответ дают данные о числе женщин в возрасте 16-49 лет с незаконнорожденными детьми среди всего женского населения в репродуктивном возрасте, которое составляло около $1 \%$, если судить по Ярославской губернии 1850 г. [Историко-статистические таблицы... 1901: 92] (по проценту внебрачных детей среди всех новорожденных губерния занимала срединное положение среди 50 губерний России). Тогда можно предположить, что женщин с внебрачными детьми уже в середине XIX века насчитывалось около 260 тыс. Они распределялись неравномерно между городом и деревней. В целом по стране в 1859-1863 гг. в городах рождалось около 26\% внебрачных детей, а в деревне - 74\%, в 1910 г. - соответственно 41 и 59\% [Военностатистический сборник 1871: 66-68; Движение населения... 1916: 51]. Распределение внебрачных детей между городом и деревней зависело от наличия в губернии крупных городов. Например, в 1850-е годы в одной Москве рождалось около 67\% всех незаконнорожденных Московской губернии. В Ярославской губернии с развитыми городами, но менее значительными, чем Москва, в городах сосредоточивалось 55\% всех внебрачных детей губернии, а в Полтавской губернии, где отсутствовали крупные города, доля незаконнорожденных в городах составляла всего 25\%, а остальные $75 \%$ находились в деревнях $^{3}$ [Историко-статистические таблицы... 1901: 92]. Как видим, женщин, стремившихся избавиться от нежеланного ребенка, уже перед эмансипацией было много и в городе, и в деревне; после эмансипации их стало еще больше.

Доля зарегистрированных православными священниками незаконнорожденных детей в общем числе новорожденных в конце XVIII-первой половине XIX века колебалась от $2 \%$ в Киевской губернии до $7 \%$ в Московской губернии, составляя, в среднем по Европейской России, 3,3\% ${ }^{4,5}$ [Памятная книжка... 1861: 325; Памятная книжка... 1871: 137140; Лаптев 1861: 169, 180; Сталь 1867: 205; Липинский 1868: 443]. Это несколько меньше, чем в западноевропейских странах, где доля незаконнорожденных оценивается в 2\% в 1680 г. и 6\% в 1820 г. [Riddle 2001: 186]. В пореформенное время число внебрачных детей в абсолютном значении увеличивалось, но очень незначительно: в Европейской России в 1859-1863 гг. их регистрировалось в среднем в год 99 тыс. [Военно-статистический сборник 1871: 66-68], в 1910 г. - 106 тыс. $^{6}$ [Щербинин 2002: 142-146]. Вследствие более быстрого роста населения процент зарегистрированных внебрачных детей у православных снижался:

\footnotetext{
2 Детальный анализ положения незаконнорожденных детей, особенно принадлежавших солдаткам, см. [Щербинин 2004].

${ }^{3}$ Архив РГО. Разр. 22. Оп. 1. Д. 3. Д. 1, 2; РГИА. Ф. 796. Оп. 138. Д. 2476 (Полтавская губерния).

${ }^{4}$ РГИА. Ф. 796 (Канцелярия Синода). Оп. 63. Д. 69; Оп. 445. Д. 423, 426; Оп. 95. Д. 1189; Оп. 96. Д. 1007; Оп. 104. Д. 1364; Оп. 128. Д. 2192; Оп. 131. Д. 260.

${ }^{5}$ Архив РГО. Разр. 22. Оп. 1. Д. 3 (Московская); Разр. 16. Д. 1 (Киевская).

6 Значительную долю среди них составляли дети солдаток.
} 
в 1859-1863 гг. он составил 3,4\%, в 1870 г. - 3,0\%, в 1885 г. - 2,7\%, а в 1910 г. -2,3\% ${ }^{7}$. Итак, получается, что по мере модернизации, урбанизации и индустриализации происходило относительное уменьшение числа внебрачных детей среди православных женщин, в то время как у старообрядцев, католиков, протестантов и иудеев оно увеличивалось. Как можно объяснить этот парадокс? Есть исследователи, которые считают имеющиеся данные о внебрачных детях заниженными по той причине, что со временем изменялись методика их учета и политика воспитательных домов в отношении приема внебрачных детей [Ransel 1982: 11-27]. Однако это не может объяснить сокращение процента незаконнорожденных детей в 1,5 раза, т.к. означало бы ежегодный недоучет нескольких десятков тысяч новорожденных. Единственное удовлетворительное объяснение, по моему мнению, состоит в том, что женщины, вступавшие во внебрачные отношения, применяли противозачаточные способы, а забеременевшие вне брака избавлялись от плода путем аборта. Только это объяснение может примирить противоречащие на первый взгляд факты, наблюдавшиеся в пореформенное время: 1) число незамужних женщин, вступавших во внебрачные половые связи, по общему мнению современников, возрастало; 2) возможность скрыть факт беременности и внебрачного рождения как от родственников, так и от священников увеличивалась; 3) среди старообрядцев, католиков, протестантов, иудеев и мусульман женщины, не состоявшие в браке, но рожавшие детей, не осуждались столь сурово, как среди православных, а их дети не дискриминировались; 4) женщинам не было смысла уклоняться от регистрации внебрачного ребенка, во-первых, потому, что, согласно религиозным представлениям, некрещеный младенец не попадал в рай, во-вторых, потому, что воспитательные дома, куда можно было сдать ребенка, в 1891 г. ввели ограничения на их прием: стали требоваться свидетельства от полиции или священников, подтверждающие, что приносимые в дома дети незаконнорожденные ${ }^{8}$ [Афиногенов 1903: 76]. Если наше предположение верно, то число женщин, прибегавших к предупреждению зачатия или делавших аборт в течение года, к 1910 г. превышало 125 тыс. Эта цифра получена следующим образом. В 1859-1863 гг. число внебрачных детей составляло 99 тыс., а их доля среди всех новорожденных - 3,4\%. Если бы женщины не применяли меры против рождения внебрачных детей, то их число должно было бы составить в 1910 г. 232 тыс. (по проценту незаконнорожденных в 1859-1863 гг. от общего числа новорожденных в 1910 г.). Между тем фактически было зарегистрировано 106 тыс. внебрачных детей.

Рост числа подкидышей мог бы служить хорошим показателем увеличения количества нежеланных детей. Но, хотя дети подкидывались по всей России на протяжении всего изучаемого периода, полных сведений об этом нет. В 1867 г. официальные данные о подкинутых младенцах в Европейской России были единственный раз опубликованы подкидышей оказалось 2254. Как указали составители статистического сборника, в котором эти данные были опубликованы, сведения неполны [Движение населения... 1872: IX, 10 11]. Увеличение числа лиц, привлеченных к уголовной ответственности за подкидывание

\footnotetext{
${ }^{7}$ C 1870 г. данные о незаконнорожденных публиковались в ежегоднике «Движение населения в Европейской России».

${ }^{8}$ Матери внебрачных детей стремились скрыть факт рождения не от священников, а от родственников и знакомых. С этой целью они нередко при приближении родов изменяли место жительства: крестьянки уходили в город, горожанки переезжали на другую квартиру или в другой город. Этот факт отмечен в беллетристике; см., например, роман Крестовского «Петербургские трущобы».
} 
младенцев, свидетельствует о росте этого явления. В 1839 г. за подкидывание младенцев были привлечены 47 мужчин и 123 женщины, в 1873 г. - соответственно 93 и 118, в 1892 г. - 206 и 805, в 1913 г. - 410 и 1759 [Свод статистических сведений... 1875, 1896, 1916]. В действительности число подкинутых младенцев было во много раз больше, например, в 1867 г., согласно крайне неполным официальным данным, было подброшено младенцев в 10 раз больше числа лиц, привлеченных к уголовной ответственности за подкидывание. Распространение детоубийств также может служить указанием на то, что для многих женщин дети становились нежеланными и они пытались от них избавиться [Успенский 1954: 110-114].

Более адекватное представление о динамике числа нежеланных детей дает деятельность двух самых больших воспитательных домов в России, находившихся в Москве и Петербурге. По подсчетам Д. Рансела, в 1791-1800 гг. в оба дома поступали ежегодно 3342 младенца, в 1841-1850 гг. - 13 092, в 1871-1880 гг. - 20 169, в 1881-1890 гг. - 24 298, в 1891-1900 гг. - 17 785, в 1901-1910 гг. - 19 218, т.е. с конца XVIII до начала XX века число подкидышей возросло в 5,8 раза, в то время как население России увеличилось в 2,9 раза [Ransel 1988: 303-308]. Число подкидышей, принятых в воспитательные дома, зависело не только от количества матерей, желавших их сдать, но и от возможностей и политики воспитательных домов. Поэтому, например, снижение числа подкидышей в 18911910 гг. вовсе не означает, что число нежеланных детей стало меньше, просто воспитательные дома ввели ограничения на их прием, что сразу уменьшило количество желающих сдавать в них детей.

Поскольку добрачный секс осуждался и наказывался, до 1914 г. большинство людей обоего пола, за исключением дворянства и интеллигенции, половую жизнь начинали после вступления в брак. Средний возраст всех женихов и невест, вступавших в первый брак, можно считать примерным возрастом полового дебюта. В 1867-1910 гг. он составлял у женихов 24,2 года, а у невест 21,4 года [Тольц 1977: 139]. Одни авторы, опираясь на отдельные свидетельства, а не на статистику, утверждают, что в конце XIX века среди крестьян девственность сохраняли менее половины мужчин [Крюкова 1992: 48; Тихонов 1891: $136^{9}$ ]. Другие говорят о полной свободе сексуальных связей между парнями и девушками и даже о таком сохранившемся первобытном пережитке, как «свальный грех»: на посиделках молодежь, оставшись одна, гасила лучину и вступала между собой в свободные отношения [Семенов 1996: 39-46; Балов 1898]. Как распространенный обычай это представляется маловероятным. Если огромное большинство женщин хранили до брака девичью честь, то как же мужчины находили партнерш, ведь проституция в деревне была явлением редким?! Если бы широко бытовали вольные отношения до брака, то, несомненно, рождалось бы много незаконнорожденных детей, что не зафиксировано в источниках. Можно допустить существование подобных пережитков у сектантов, у жителей глухих отдаленных деревень. Например, у старообрядцев внебрачные связи допускались и рожденные от них дети признавались наряду с законными [Бушнелл 2011]. За сексуальную свободу городские наблюдатели, вероятно, принимали обычай,

\footnotetext{
${ }^{9}$ В.П. Тихонов утверждал: «Почти все игры местной молодежи имели своим финалом - вступление в половое общение».
} 
существовавший, например, в деревнях Саратовской губернии: «После посиделок девки оставляли парней ночевать. Ложась с избранными парубками, они дозволяли им себя целовать, но до греха дело доходило редко» [Минх 1890: 110].

Однако в больших городах среди студенческой молодежи сексуальный опыт начинался раньше: по сведениям опроса двух тысяч харьковских студентов в 1902 г., у 73\% - в возрасте 17-20 лет [Фавр 1910]; согласно аналогичному опросу 2150 московских студентов в 1904 г., у 50\% - в возрасте 14-17 лет, в том числе у 22\% - в возрасте 16 лет [Членов 1907: 1072-1111]. Аналогичные результаты так называемых «половых переписей студентов» получены для университетов Томска и Юрьева (Тарту). В 1908 г. В. Жбанков провел первое в мире анкетное обследование сексуальной жизни 6 тыс. студенток и учительниц Москвы, 80\% которых находилось в возрасте до 25 лет. Это было настолько новым и вызывающим, что полиция конфисковала ответы на анкету. Анализ сохранившихся 324 ответов показал: почти 90\% московских студенток и учительниц в возрасте от 17 до 20 лет были девственницами, в возрасте 21-25 лет - 45,4\%. Среди тех, кто никогда не состоял в формальном браке, доля имевших сексуальный опыт составляла $18 \%$ [Жбанков 1922: 225]. Для сравнения: в 1957 г. среди ленинградских студентов невинность до 16 лет сохранили 99\% девушек, в 1971 г. - 94\%, в начале 2000-х годов - 42\%. В 2000-е годы $20 \%$ школьниц старших классов живут половой жизнью и отличаются высокой сексуальной активностью. Уже в 1990-е годы сексуальная активность российской молодежи начиналась раньше, чем у британцев, американцев или норвежцев [Голод 1996: 59; Денисенко, Далла Зуанна 2001: 83-87; Кон 1990: 171; 1997: 291].

\section{Регулирование рождаемости}

В последней трети XIX века методы регулирования рождаемости стали постепенно входить в жизнь сначала в городах в среде образованных и состоятельных слоев населения ${ }^{10}$ [Мельцин 1999: 55-62], а затем и среди городских низов и крестьянства [Мухина 2012: $147-$ 160; Вишневский 2005: 1: 271-276; Дьячков 2003: 207; Моисеенко 1984: 73-86; McLaren 1990; Riddle 1997].

\section{Судебный следователь В. Магнитский представил в 1871 г. в Русское} географическое общество очерк о преступности, в котором сообщил, что изгнание плода у русских считается страшным грехом, тем не менее в каждом селении есть женщины, занимающиеся этим ${ }^{11}$. Чтобы вызвать искусственный выкидыш, крестьянки использовали механические средства (поднятие тяжестей, прыжки, тугое бинтование и разминание живота, трясение всего тела и др.), лекарственные средства (от различных трав до ртути и фосфора, употребляемых внутрь), вытравливание плода, удлинение лактационного периода и аборт. Для изгнания плода знахарки дают пить сулему или советуют глотать жестяные кружочки. Для предотвращения беременности женщины тотчас после полового акта пьют ложку воды с порохом, обмыв руки своей мочой ${ }^{12}$ [Афиногенов 1903: 327; Федоров 1994 :

${ }^{10}$ В последней трети XIX-начале XX века князья Долгоруковы сознательно регулировали рождаемость, чтобы ограничить число наследников.

${ }^{11}$ Арх. РГО. Разр. 14. ОП. 1. Д. 27.

12 Там же. 
18; Щербинин 2004: 127-128]. Эти весьма несовершенные средства давали некоторый эффект [Пилсудский 1910: 14-16].

Согласно свидетельству священника Новгородской губернии Ф.В. Гиляровского, в 1860-е годы крестьянки, стремившиеся предотвратить беременность, увеличивали срок кормления грудью «далее пределов законных - двух великих постов», т.е. более 2 лет. «Матери продолжают кормить грудью ребенка до четырех и до пяти лет и кормят чужого, иногда и беззубых щенят, не говоря уже об извлечении ими своего молока и более неестественным способом» [Гиляровский 1866: 50]. Продление лактации широко практиковалось и в других губерниях [Афиногенов 1903: 99], эта практика сохранялась еще в 1920-е годы. «Если последующая беременность долго не наступает, - отмечалось в одном исследовании 1920-х годов, - кормят, пока ребенок не застыдится, - до 4, 5 и 7 лет» [Синкевич 1929: 58-59]. Этот метод до некоторой степени защищал женщин от новой беременности, так как, по данным русских врачей, около 80\% женщин не имели менструаций при кормлении грудью ${ }^{13}$.

К началу XX века ассортимент средств контроля над рождаемостью увеличился: воздержание, цикличность и прерванный половой акт; презервативы, маточные кольца, противозачаточные колпачки, вагинальное спринцевание и свечи. Однако ими пользовались только образованные и состоятельные женщины. Контрацепция среди них стала настолько популярной темой, что известное пособие К.И. Дрекслера «Предохранительные средства в современном браке» в 1907-1914 гг. вышло семью изданиями [Дрекслер 1929; Беллин 1889; Боряковский 1893; Ван-дер-Борн 1909; Войцеховский 1888; Попов 1903; Роледер 1909].

Aборты. По духовным законам все средства прерывания беременности считались грехом, и по церковному уставу вытравливание плода зельем или с помощью бабкиповитухи наказывалось епитимьей сроком от 5 до 15 лет. По гражданским законам аборт был запрещен и уголовно наказуем, причем привлекались к ответственности как врачи, так и пациенты. Уложение о наказаниях 1845 г. приравнивало плодоизгнание к детоубийству и карало каторжными работами сроком от 4 до 10 лет. Взгляд на применение любых способов предотвращения беременности и вызывания искусственного выкидыша как на большой грех был так распространен, что женщины, которые пользовались ими, тщательно скрывали это от всех (и от соседей, и от врачей) даже в 1920-е годы, когда аборты были официально разрешены [Синкевич 1929: 46; Лебина 2007]. Выкидыши чаще всего зарывают в землю, в подполье, реже их прячут в навозные кучи и бросают зимой в речки и ручейки. Долгое время к аборту отрицательно относились не только церковь и законодательство, но и врачи [Лебина 2007; Engelstein 1991: 185-207; 1992: 334-358]. В 1889 г. на Третьем съезде Общества русских врачей в память Н.И. Пирогова аборт был признан «нравственным и социальным злом». За 1840-1890 гг. во всех российских родовспомогательных учреждениях было сделано всего 247 официально разрешенных по медицинским соображениям абортов, к 1910 г., если судить по Петербургу и Москве, их число возросло почти в 5 раз, но все

13 Григорьев И. (1883). О половой деятельности женщин Мышкинского уезда Ярославской губернии // Врачебные ведомости. 21/23. 
равно оставалось невысоким [Михайлов 1895: 417; Демографическая модернизация России, 2006: 42].

Время, однако, работало в пользу либерализации аборта. Врач А.О. Афиногенов, практиковавший в конце XIX-начале XX века, и многие участники Двенадцатого съезда Общества русских врачей 1913 г. отмечали, что уже в 1880-х годах в деревнях, особенно в подгородных, стали входить в практику аборты [Афиногенов 1903: 57, 99; Двенадцатый съезд... 1913: 2: 92, 211]. В деревнях они производились преимущественно «бабками» и знахарками ${ }^{14}$ [Семенова-Тян-Шанская 1914: 56-58]. Горожане познакомились с абортом раньше, и в начале XX века промышленные города были охвачены «эпидемией абортов». «В рабочей среде стали смотреть на искусственный выкидыш как на нечто весьма обыденное и притом весьма доступное» [Вигдорчик 1914: 217]. Харьковский врач П.Н. Чухнин, оценивший в 1893 г. число абортов и выкидышей в 22\% от всех беременностей, заметил: «Многие из его больных заявляли о своем нежелании иметь детей и многие говорили о тех мерах предосторожности, которые они предпринимали, чтобы предохранить себя от беременности; если прибавить к этому, что некоторые выкидыши вызваны были, по-видимому, умышленно, то мы увидим, что у современной женщины существует сильное стремление к ограничению числа беременностей» [Чухнин 1894: 1: $533]$.

О числе «криминальных» абортов невозможно даже весьма приблизительно судить по данным о привлеченных за них к уголовной ответственности, так как они тщательно скрывались от церковных и светских властей. В 1830-е годы за «истребление беременности» привлекались в среднем в год по 108 мужчин и 284 женщины [Отчет Министерства юстиции 1835-1841]. В последующие годы число абортов увеличилось. Несмотря на это, в 1873 г. было осуждено 7 мужчин и 10 женщин, в 1892 г. - соответственно 3 и 16, в 1913 г. - 34 и 210 [Свод статистических сведений. . 1875, 1896, 1916]. В 1897-1906 гг. в России в среднем в год за истребление плода осуждалось 8 женщин [Гернет 1911: 67], в 1910-1916 гг. - от 20 до 51 [Безгин 2004: 174], обвинялось в 2,5 раза больше. Уменьшение репрессии объяснялось тем, что по новым судебным уставам 1864 г. преследование за аборт ослабло, «преступники» научились скрываться от правосудия, но самое, пожалуй, главное - не только общество, но и правоохранительные органы стали более снисходительно смотреть на искусственное прерывание беременности. В 1913 г. под влиянием общественного движения за отмену уголовного преследования врачей и пациентов за производство абортов Двенадцатый съезд Общества русских врачей поддержал это требование, хотя и не единодушно. В феврале 1914 г. в Петербурге проходило заседание Русской группы Международного союза криминалистов, посвященное абортам. В нем приняли участие виднейшие русские врачи, криминалисты и юристы. Были выслушаны два доклада. М.Н. Гернет отстаивал необходимость полной легализации, а Е.М. Кулишер частичной легализации аборта (разрешать только по медицинским соображениям). После жаркой двухдневной дискуссии, в которой участвовали 30 человек, группа приступила к принятию резолюции. Большинством голосов (38 против 20 при 3 воздержавшихся) прошел проект Гернета, требующий исключить из числа преступных деликтов аборт [Двенадцатый

${ }^{14}$ Арх. РГЭМ. Ф. 7. Оп. 1. Д. 68, 216, 473, 499, 552. 
съезд... 1913: 2: 25, 88, 92, 211; Гернет 1916; Кулишер 1916; Отчет Х общего собрания... 1916: 271-333, 354-398, 400]. Однако последний был легализован только в 1920 г. [Попов 1994: 5-7], хотя, несомненно, раньше применялся, но под большим секретом. Предполагалось, что перед судом предстали менее $1 \%$ женщин, сделавших аборт, причем в 75\% случаев они были оправданы [Третий съезд Общества ... 1889: 177-178; Гернет 1916: 237-238]. Согласно приблизительной и сильно завышенной оценке, в Петербурге в последней трети XIX века число абортов возросло в 10 раз и составило около $20 \%$ от числа рождений [Садвокасова 1969: 12], в Москве в 1910-е годы - около 10 тыс. в год [Третий съезд Общества... 1889: 177-178; Гернет 1916: 237-238].

Презервативы. Важным средством предотвращения беременности становились также презервативы. Например, не в самом большом городе России Харькове они вошли в употребление с конца 1860-х годов [Багалей, Миллер 1912: 2: 123]. С 1890-х годов образованные слои населения стали повсеместно и широко их применять. Однако по религиозным причинам и из-за дороговизны в крестьянский быт они не входили. Презервативы рекламировались в газетах и продавались во всех аптеках, магазинах медицинских инструментов и резиновых изделий [Боряковский 1893: 886-887: Милютин 1946: 93-94]. В 1911-1913 гг., согласно прейскуранту на импортные презервативы (в России они не производились) известных петербургских магазинов резиновых изделий Г. Годефруа или Д. Роджерс и других фирм, они стоили за дюжину из резины от 0,8 до 6 руб., из рыбьего пузыря - от 2,5 до 7 руб., т.е. за один - от 7 до 59 коп., но поштучно они не продавались. Чтобы купить дюжину самых дешевых презервативов, крестьянину или рабочему нужно было один день трудиться на самых тяжелых работах [Сборник статистико-экономических сведений... 1917: 526-527; Города России... 1914: 30, 118-119, 264-265, 434-435]. Это дороговато, но все же было доступно. Однако если в больших городах презервативы можно было свободно купить, то жителям большинства городов и сельских поселений их нужно было заказывать почтой и оплачивать пересылку, стоимость которой намного превышала цену товара. Простому труженику (крестьянину, рабочему, ремесленнику или мещанину) это было не под силу по причине дороговизны и неграмотности.

Регулирование рождаемости постепенно входило в жизнь и начинало приносить свои результаты. За 30 лет с 1880-х до 1910-х годов общая рождаемость в целом по стране понизилась лишь на 6,5 пункта (с 50,4 до 43,9 промилле). Это говорит о том, что контроль над числом детей не вошел в практику широких слоев населения. По расчету А.Г. Вишневского, на рубеже XIX-XX веков российские женщины лишь наполовину использовали свой биологический потенциал (вместо 12-13 раз рожали в среднем 6-7 ра3 ${ }^{15}$ [Новосельский 1914]), главным образом вследствие того, что вступали в брак в более позднем возрасте, чем прежде (2,38 рождений), из-за плохого состояния здоровья и намеренного предотвращения рождений (1,60 рождений) и из-за преждевременной смерти (1,26 рождений). Как видим, регулирование могло объяснить незначительную долю понижения рождаемости (таблица 16).

15 Суммарный коэффициент рождаемости в 1896-1897 гг. равнялся 7,06. 
Таблица 16. Факторы, определявшие среднее число детей, приходившихся на одну женщину в России на рубеже XIX-XX веков

\begin{tabular}{lr}
\hline Среднее число детей, которое могла бы родить женщина за свою жизнь & 12,44 \\
Родила & 6,24 \\
Не родила & 6,20 \\
В том числе: & 1,26 \\
$\quad$ из-за смерти некоторых женщин до 50 лет & 0,55 \\
$\quad$ из-за того, что некоторые женщины не вступили в брак & 2,38 \\
$\quad$ из-за того, что не все вступили в брак в 16 лет & 0,41 \\
$\quad$ из-за пребывания вне брака после овдовения & 1,60 \\
$\quad$ из-за плохого состояния здоровья или намеренного предотвращения рождений & \\
\hline
\end{tabular}

Источник: [Воспроизводство населения... 1983: 282].

Сельскую глубинку, где проживало большинство населения, новые веяния затронули очень мало. Согласно данным обследования, проведенного в 1927 г., через 10 лет после революции, когда аборты и контрацепция уже не запрещались, среди замужних украинских крестьянок, лишь 9\% использовали тот или иной способ предотвращения зачатия, чаще всего coitus interruptus [Томилин 1987: 107-109]. В 1990-1993 гг. Дэвид Рансел провел полевые исследования среди российских крестьянок Новгородской, Смоленской, Московской, Свердловской и Ульяновской областей с целью проследить изменения в представлениях о браке, регулировании рождаемости, родах, уходе за детьми за годы советской власти. Было взято и записано на магнитофон 89 глубоких интервью (по анкете, включавшей 44 вопроса) у 70 русских и 19 татарских женщин. В качестве респондентов выбирались, во-первых, женщины, которые провели всю жизнь в деревне, во-вторых, женщины разных возрастов. Рансел разделил всех опрошенных на три поколения: рожденные в 1899-1911 г. - 27 человек, в 1912-1930 гг. - 45 человек и в 1931-1954 гг. - 17 человек. Анализ интервью привел к следующим выводам. Первое поколение женщин, рожденных в 1899-1911 гг., провело детство при старом императорском режиме, а молодость - в советской доколхозной деревне. Они много рожали; вмешательство в таинство зачатия и рождения считали греховным делом и попытки регулирования их числа сводились к удлинению срока лактации; относились резко отрицательно к аборту, поэтому мало кто из них воспользовался легализацией аборта в 1920-1936 гг. Боялись сглаза, поэтому рожали без посторонних (либо самостоятельно, либо с помощью повивальной бабки) и через несколько дней приступали к работе. Женщины второго поколения, рожденные в 1912-1930 гг., по большей части росли и воспитывались при советской власти и колхозном строе. Они контролировали рождаемость посредством презервативов и нелегальных абортов, поскольку почти весь репродуктивный период их жизни приходился на период запрещения последних (1936-1955 гг.). Женщины третьего поколения, рожденные в 1931-1954 гг., как правило, вступали в брак в послесталинский период. Они свободно контролировало рождаемость посредством аборта и презерватива. Татарские крестьянки имели с русскими больше общего, чем различного. Первое их поколение не знало никакой контрацепции, отрицательно относились к аборту. Второе поколение также не предпринимало практических мер по регулированию рождаемости, кроме продления лактации, не признавало аборт, а презервативы не вошли в употребление по причине возражения мужчин. Только третье поколение татарских крестьянок стало регулировать рождаемость главным образом с помощью аборта и презерватива [Ransel 2000]. 
Иная картина наблюдалась среди жителей больших городов и привилегированных слоев населения. Рождаемость в Петербурге с 1861-1865 по 1911-1915 гг. упала с 38 до 26 на 1000 человек населения, в Москве она уже в 1867-1880 гг. равнялась всего 23 на 1000, но, в отличие от Петербурга, к 1911-1913 гг. повысилась до 29 на 1000 вследствие огромного притока крестьян [Рашин 1956: 234, 239]. Данный уровень рождаемости свидетельствует о том, что она стала регулироваться. Об этом говорит и тот факт, что общая и брачная рождаемость имела не только межсословные, но и внутрисословные отличия. В Петербурге в 1907-1912 гг. женщины бедных классов рожали в 3 раза чаще, чем представительницы богатых слоев, жены квалифицированных рабочих рожали в 2 раза реже, чем жены неквалифицированных рабочих [Новосельский 1978: 136-142; Вигдорчик 1914]. Опрос 2150 студентов Московского университета в 1904 г. преимущественно из среднего класса (67\% назвали имущественное положение своих семей средним) обнаружил: меры против зачатия применяли 57\% (25\% - прерванное сношение, 16\% - презервативы, $15 \%$ - другие) [Членов 1907].

\section{Разводы}

До начала XVIII века расторжение брака являлось прерогативой священника соответствующего прихода. Брачные споры в среде привилегированных слоев разрешались преимущественно на основе византийского церковно-судебного законодательства, пришедшего на Русь в переводе на церковнославянский язык. Но в отношении к простому народу священники часто руководствовались обычным правом, и поэтому насчитывалось до 26 законных поводов. Для развода обоим супругам достаточно бы сделать заявление своему приходскому священнику и получить от него так называемое разводное письмо [Владимирский-Буданов 1900: 439-439; Рабинович 1978: 215-216]. В некоторых случаях обходились и без священника. При согласии супругов на развод муж выдавал жене «бракоразводную грамоту» и «отступное письмо», что заменяло решение священника. Сложнее было, если одна из сторон не желала развода: он становился делом очень трудным [Латкин 1909: 520-524]. «Самовольные расходы» или «самовольные разъезды», как они назывались в обиходе, имели место в течение всего изучаемого времени. Дать количественную оценку этому явлению невозможно - оно не регистрировалось. Однако, согласно свидетельствам современников, на рубеже XIX-XX веков «разъезды» были более распространены сравнительно с XVIII-началом XIX века, что дает основание для предположения, что со временем их частота увеличивалась. Они практиковались среди всех сословий $^{16}$ [Розанов 2004: 298-299; Иванилова 2002: 127-129]. Информатор Этнографического бюро В.Н. Тенишева из Калужской губернии отмечал в 1900 г., что формального церковного развода среди крестьян не бывает - они о нем не имеют понятия. Супруги расходятся фактически, живут отдельно, иногда заводят новую семью, разведенные женщины часто уходят в Москву и иногда живут без венчания с вдовцами. Нередко крестьяне обращаются в волостной суд. Последний не может дать формального развода, а лишь решает, кто прав, кто виноват ${ }^{17}$. «Разъезды» случались чаще, чем можно

\footnotetext{
${ }^{16}$ Арх. РГЭМ, ф. 7 (В.Н. Тенишев), оп. 1, д. 32, 279, 401, 431, 517, 519, 552.

${ }^{17}$ Арх. РГЭМ. Ф. 7. Оп. 1. Д. 552. Л. 2-3; Д. 279. Л. 2-3; Д. 517. Л. 16-18; Д. 519. Л. 27. 
было бы ожидать, основываясь на нормативной модели демографического поведения ${ }^{18}$. Однако они не получили широкого распространения по причине крайне негативного отношения к ним со стороны общества, церкви и государства ${ }^{19}$ [Цатурова 2011: 93-160, 256266; Заболотная 2010].

В течение XVIII века Русская православная церковь (РПЦ) бракоразводный процесс перенесла в консистории и сделала формальным, а число поводов для формального развода сократила до четырех: 1) доказанное прелюбодеяние; 2) неизвестное длительное отсутствие; 3) приговор суда к наказанию, сопряженному с лишением всех прав состояния; 4) пострижение в монашество при условии обоюдного полюбовного соглашения супругов в отношении пострижения одного из них в монастырь, при одновременном пострижении, при достижении женою 50-летнего возраста, при отсутствии малолетних детей. Несогласие между супругами, физические недостатки, тяжелые болезни, побои не служили формальным основанием для развода, но они давали некоторое право для разлучения супругов. Установление близкого родства и вступление одного из супругов в отсутствие другого в новый брак делало заключенный прежде брак незаконным и недействительным [Свод законов... 1857; Латкин 1909: 520-521]. В 1806 г. появился пятый повод для законного развода - «физическая неспособность к брачному сожитию», что было равносильно признанию тяжелой болезни в качестве основания для развода ${ }^{20,21}$. Эффективный институциональный контроль над матримониальными делами РПЦ смогла установить только после введения в практику «Устава духовных консисторий» 1841 г., который строго кодифицировал условия, необходимые для развода, и его процедуру [Фриз 2009: 125-126].

Следует принять во внимание, что супруги (как правило, женщины) могли через Канцелярию по принятию приносимых на высочайшее имя прошений добиться права на отдельное проживание без развода, что чаще всего означало фактическое прекращение брачных отношений и помогало выйти из тупика, создаваемого трудностями развода [Мареева 2003: 33-36]. В среднем в год в 1890-1902 гг. в Канцелярию женщины подавали 2327 прошений, из них было удовлетворено 1154, что на 10-20\% превышало число разводов. Интересно отметить: состав оснований для подачи и удовлетворения ходатайств был иным, чем при разводах (таблица 17).

Основания для развода, признаваемые РПЦ законными (нарушение супружеской верности; неизвестное длительное отсутствие или бродячий образ жизни; неспособность к брачной жизни), фигурировали лишь в 11,6\% прошений на раздельное проживание, в остальных случаях основаниями выступали те, которые признавала общественность и де-

18 Сведения, поступившие в Этнографического бюро В.Н. Тенишева, частично опубликованы [Быт великорусских крестьян-землепашцев... 1993; Русские крестьяне... 2004-2017].

${ }^{19}$ В православной Молдавии XVI-XVII веков семейные обычаи и традиции осуждали развод, но он, тем не менее, существовал, и женщины даже иногда выигрывали процесс.

20 Под неспособностью к супружескому сожительству имелась в виду исключительно физическая неспособность к отправлению полового акта, для чего требовалось заключение врача о неспособности мужчины и доказательства девственности женщины.

${ }^{21}$ Полное собрание законов (1850). Т.35. Отд.1. № 23906. СПб.: Типография Второго отделения собственной его императорского величества канцелярии. 
факто коронные власти [Веременко 2007: 324-337]. Если женщины хотели развестись и имели для этого достаточные формальные основания, они, как правило, обращались в суд за разводом, при отсутствии таких оснований - в Канцелярию прошений. Право на раздельное проживание являлось, по сути, заменой развода.

Таблица 17. Основания для получения разрешения на отдельное жительство от мужа в 1891 г. (лица православного вероисповедания)

\begin{tabular}{l|rr}
\hline \multicolumn{1}{c|}{ Основания } & Прошения & $\%$ \\
\hline Буйный характер, пьянство, нанесение побоев, вымогательство, растрата имущества & 233 & 39,8 \\
Жестокое обращение & 112 & 19,1 \\
Недоставление семье материальных средств & 108 & 18,5 \\
Порочный образ жизни & 51 & 8,7 \\
Нарушение супружеской верности & 50 & 8,5 \\
Бродячий образ жизни & 14 & 2,4 \\
Расстройство умственных способностей & 8 & 1,4 \\
Венерические заболевания & 5 & 0,9 \\
Неспособность к брачной жизни & 4 & 0,7 \\
Итого & 585 & 100,0 \\
\hline
\end{tabular}

Источник: [Веременко 2007: 250].

Если объединить данные о разводах и разрешениях на раздельное проживание за 1891 г. в одну совокупность, то получится: примерно в 56\% случаев причинами нежелания женщин сохранить брак являлись пресловутые пять законных оснований для разводов, а в 44\% - иные основания, не признаваемые РПЦ. Интересно отметить: основания для раздельного проживания у православных совпадали с формальными условиями для развода у российских протестантов; у католиков развод запрещался, а получение права на раздельное проживание сопряжено было с большими трудностями. По этой причине разводы у протестантов случались в 4 раза чаще, чем у православных, и в 12 раз чаще, чем У российских католиков ${ }^{22}$ [Веременко 2007: 294, 312, 318].

Таблица 18. Число расторгнутых браков среди православного населения Российской империи в 1842-1914 гг.

\begin{tabular}{l|c|c|c}
\hline Годы & Число разводов & Разводов на 1000 браков & Разводов на 1000 человек населения \\
\hline $1842-1850$ & 74 & 0,143 & 0,002 \\
$1851-1860$ & 80 & 0,156 & 0,002 \\
$1866-1870$ & 782 & 1,377 & 0,015 \\
$1871-1880$ & 917 & 1,587 & 0,016 \\
$1881-1890$ & 1068 & 1,698 & 0,030 \\
$1891-1900$ & 1047 & 1,202 & 0,012 \\
$1901-1910$ & 1921 & 2,071 & 0,021 \\
$1911-1915$ & 3650 & 4,302 & 0,037 \\
\hline
\end{tabular}

Источник: Подсчитано по: [Всеподданнейший отчет... 1842-1914].

В силу жесткого контроля церкви за разводами в позднеимперский период они стали чрезвычайным событием, и разводившихся можно считать девиантами [Бечаснов 1893: 8; Новосельский 1916а: 29; Преображенский 1901: 71-74; Freeze 1990; 2006]. По сведениям,

22 Данные за 1867-1876 гг.

В общем числе разводов и недействительных браков последние составляли в 1840 -е годы около 15\%, в 18901912 гг. $-3-6 \%$. 
поступившим из епархий в Синод, число расторгнутых браков с 1860-х годов стало быстро увеличиваться, но до 1917 г. оно оставалось на низком уровне (таблица 18)

Вместе с ростом число расторгнутых браков во второй половине XIX-начале XX века радикально изменился состав оснований для разводов (таблица 19).

Таблица 19. Основания разводов среди православного населения Европейской России в середине XIX-начале XX века, \%

\begin{tabular}{|c|c|c|}
\hline \multirow{2}{*}{ Основания разводов } & \multicolumn{2}{|c|}{ Разводы, \% } \\
\hline & $1841-1850$ гг. & 1905-1912 гг. \\
\hline Прелюбодеяние & 6,8 & 97,4 \\
\hline Неспособность к супружеской жизни & 3,3 & 2,3 \\
\hline Безвестное отсутствие и ссылка в Сибирь & 89,9 & 0,3 \\
\hline Итого & 100,0 & 100,0 \\
\hline
\end{tabular}

Источник: Подсчитано по [Новосельский 1916а: 43; Пребраженский 1901: 71-74; Всеподданнейший отчет... 1915].

До 1850-х годов главными основаниями для развода служили безвестное отсутствие супруга и ссылка в Сибирь, в начале XX века почти единственным основанием супружеская измена ${ }^{23}$ [Веременко 2007: 317]. Формальные разводы происходили главным образом в среде образованных, привилегированных слоев ${ }^{24}$ [Мельцин 1999: 271-277]. В пореформенное время они проникли в среду крестьян, мещан и купцов. По числу разведенных на 1000 человек город обгонял деревню в 3 раза; авангардный Петербург обгонял все городское население в 7 раз, а всю страну в 21 раз. Москва отставала: по переписи 1902 г. доля разведенных в населении города составляла 1\% у мужчин и 1,5\% у женщин [Перепись Москвы...1904: 112-113], т.е. в 1,6 раза меньше, чем в Петербурге. В сословном разрезе среди разведенных лидировали дворяне: в среднем по стране они разводились в 5 раз чаще, чем духовенство, и в 5 раз чаще, чем крестьяне, а в Петербурге в 7 раза чаще, чем духовенство и крестьяне (таблица 20).

В конфессиональном отношении среди разведенных лидировали иудеи, мусульмане и буддисты, затем шли протестанты, католики и последними - православные. По сравнению с русскими у евреев было разведенных примерно в 9 раз больше, у татар и башкир - в 8 раз, у немцев и эстонцев - в 3 раза, у поляков и литовцев - в 2 раза [Общий свод... 1905: т.2: $92-$ 97, 176; Веременко 2007: 374-377]. Существенное увеличение числа разводов, особенно в городе, отражало начавшиеся изменения в демографических установках населения, произошедшие в результате реформ [Белякова 2002; Котлова 2002; Максимова 1998; Мареева 2001; 2003; Веременко 2007; Лещенко 2004; Фриз 2009]. Львиная доля разводов приходилась на привилегированные образованные слои населения.

23 У католиков и протестантов оснований для разводов было больше: дополнительно злонамеренное оставление без помощи и жесткое обращение. На долю разводов по последним двум основаниям в 18781882 гг. в Варшавском консисториальном округе приходилась около половины разводов.

${ }^{24}$ Например, среди князей Долгоруких за 1711-1900 гг. имелось два двоеженца, 11 разведенных: 1- в 1730-е, 1 - 1810-е, 1 - 1830-е, 3- в 1840-е годы, 5 - в 1861-1900 гг.; большой процент холостяков и старых дев [Мельцин 1999: 271-277]. 
Таблица 20. Число разведенных в С.-Петербурге по сословиям в 1910 г.

\begin{tabular}{|c|c|c|c|c|c|c|}
\hline \multirow[b]{2}{*}{ Сословные группы } & \multicolumn{4}{|c|}{ Число разведенных } & \multirow[b]{2}{*}{$\begin{array}{c}\text { Численность } \\
\text { сословия в } \\
\text { населении, \% }\end{array}$} & \multirow[b]{2}{*}{$\begin{array}{c}\text { Разводимость } \\
\text { (столбец } 5 \text { к } \\
\text { столбцу 6) }\end{array}$} \\
\hline & 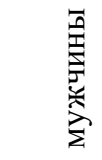 & 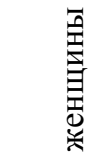 & 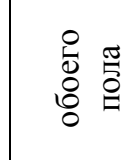 & $s^{2}$ & & \\
\hline 1 & 2 & 3 & 4 & 5 & 6 & 7 \\
\hline Дворяне & 452 & 583 & 1035 & 26,4 & 7,2 & 3,7 \\
\hline потомственные & 299 & 299 & 598 & 15,3 & 3,9 & 3,9 \\
\hline личные & 153 & 284 & 437 & 11,1 & 3,3 & 3,4 \\
\hline Духовенство & 4 & 6 & 10 & 0,3 & 0,5 & 0,5 \\
\hline Почетные граждане & 169 & 131 & 300 & 7,7 & 4,1 & 1,9 \\
\hline Купцы & 42 & 36 & 78 & 2,0 & 0,7 & 2,8 \\
\hline Мещане & 297 & 548 & 845 & 21,6 & 15,5 & 1,4 \\
\hline Отставные нижние чины & 1 & 1 & 2 & 0,1 & 0,1 & 0,5 \\
\hline Крестьяне & 522 & 780 & 1302 & 33,2 & 68,8 & 0,5 \\
\hline Финские уроженцы & 13 & 44 & 57 & 1,5 & 0,9 & 1,6 \\
\hline Иностранные подданные & 38 & 87 & 125 & 3,2 & 1,2 & 2,7 \\
\hline Неизвестно & 38 & 128 & 166 & 4,2 & 1,1 & 4,0 \\
\hline Итого & 1576 & 2344 & 3920 & 100,0 & 100,0 & 1,0 \\
\hline Население, тыс. & 997,2 & 908,4 & 1905,6 & & & \\
\hline $\begin{array}{l}\text { Разведенных на } 1000 \\
\text { человек }\end{array}$ & 1,6 & 2,6 & 2,1 & & & \\
\hline
\end{tabular}

Источники: [Петроград по переписи... 1915: ч.1: 26-35; Веременко 2007: 376-377].

Таблица 21. Число разводов на 1000 человек населения в 1800-1960-е годы в России и ряде других стран*

\begin{tabular}{l|c|c|c|c|c|c|c|c}
\hline \multirow{2}{*}{ Страна } & \multicolumn{8}{c}{ Годы } \\
\cline { 2 - 9 } & $1800-\mathrm{e}$ & $1850-\mathrm{e}$ & $1880-\mathrm{e}$ & $1900-\mathrm{e}$ & $1920-\mathrm{e}$ & $1930-\mathrm{e}$ & $1950-\mathrm{e}$ & $1960-\mathrm{e}$ \\
\hline Россия & - & 0,028 & 0,032 & 0,01 & 2,0 & 2,6 & 1,8 & 4,1 \\
Австро-Венгрия* & - & 0,055 & 0,01 & 0,01 & - & 0,5 & 2,6 & 2,4 \\
Англия & - & 0,005 & 0,015 & 0,02 & 0,2 & 0,2 & 1,2 & 1,6 \\
США & - & 0,3 & 0,42 & 0,80 & 3,1 & 3,3 & 4,7 & 5,3 \\
Германия & - & 0,035 & 0,09 & 0,20 & 1,1 & 1,4 & 2,0 & 1,9 \\
Франция & 0,02 & 0,035 & 0,09 & 0,25 & 1,1 & 1,1 & 1,5 & 1,3 \\
Япония & - & - & - & 1,10 & 1,7 & 1,4 & 1,7 & 1,6 \\
\hline
\end{tabular}

* С 1918 г. Австрия.

Источник: [Миронов 2015: т.3: 353-356].

Таким образом, закон, обычай и практика позволяли человеку расторгнуть брак, когда он становился для него неприемлемым. Главная трудность заключалась не в отсутствии формальных возможностей, а в том, что их реализация требовала знаний, времени, средств и наталкивалась на противодействие самого населения (особенно крестьянства), отрицательно относившегося к расторжению брака. Поэтому разводы случались крайне редко - максимально в 1910-1914 гг. в среднем в год 3,7 расторжения на 1000 браков. Для сравнения через 100 лет, в 2010-1914 гг., - 535 разводов на 1000 браков, т.е. в 146 раз больше.

Если сравнить Россию с другими европейскими странами, США и Японией, то окажется, что на начало XX века (1901-1905 гг.) в большинстве не только протестантских, но даже католических стран (где развестись было труднее, чем в России) число разводов на 
1000 человек был существенно выше: в Великобритании - 0,02; Франции - 0,25; Германии - 0,2; в США - 0,8; в Японии - даже 1,1, а в России - 0,01 (таблица 21).

\section{СОЦИАЛЬНЫЕ И ЭТНИЧЕСКИЕ ОСОБЕННОСТИ ДЕМОГРАФИЧЕСКОГО ПЕРЕХОДА}

Глубину вовлеченности населения в демографический переход помогают оценить степень изменений в демографических показателях и масштабы охвата ими различных регионов и отдельных социальных слоев населения. Демографические инновации в городе проходили интенсивнее, чем в деревне, в крупных городах значительнее, чем в малых, среди привилегированных и образованных слоев быстрее, чем среди низших классов населения, в западных губерниях начались раньше, чем в центральных и восточных (таблица 22).

Таблица 22. Отклонение общей рождаемости от максимально возможной $\left(I_{f}\right)$, в том числе за счет изменений рождаемости в браке $(\mathrm{Ig})$ и доли состоящих в браке $\left(I_{m}\right)$ с учетом внебрачной рождаемости $\left(I_{h}\right)$ в 1896-1897 гг. Европейская Россия и группы входящих в нее губерний*

\begin{tabular}{l|c|c|c|c|c}
\hline Территория & $\begin{array}{c}\text { Население, } \\
\%\end{array}$ & $\begin{array}{c}\text { Общая } \\
\text { рождаемость } \\
\left(I_{f}\right)\end{array}$ & $\begin{array}{c}\text { Брачная } \\
\text { рождаемость } \\
(I g)\end{array}$ & $\begin{array}{c}\text { Доля } \\
\text { состоящих в } \\
\text { браке }\left(I_{m}\right)\end{array}$ & $\begin{array}{c}\text { Внебрачная } \\
\text { рождаемость } \\
\left(I_{h}\right)\end{array}$ \\
\hline Европейская Россия & 100,0 & 0,54 & 0,76 & 0,69 & 0,047 \\
$\quad \begin{array}{l}\text { городское население } \\
\quad \text { сельское население }\end{array}$ & 12,9 & 0,39 & 0,66 & 0,56 & 0,044 \\
Группь губерний & 87,1 & 0,56 & 0,78 & 0,71 & 0,019 \\
Неземледельческий центр & 18,2 & 0,49 & 0,74 & 0,63 & 0,065 \\
Земледельческий центр & 30,0 & 0,59 & 0,79 & 0,74 & 0,033 \\
Окраинные колонизируемые & 19,6 & 0,59 & 0,76 & 0,76 & 0,047 \\
Запад и Юго-Запад & 21,0 & 0,48 & 0,74 & 0,64 & 0,037 \\
Север и Северо-Восток & 8,6 & 0,56 & 0,78 & 0,68 & 0,076 \\
Прибалтика & 2,6 & 0,29 & 0,57 & 0,49 & 0,032 \\
\hline
\end{tabular}

* Приведенные показатели (индексы Коула) связаны между собой следуюшим соотномением: $I_{f}=I_{g} I_{m}+\left(1-I_{m}\right) I_{h}$. За максимум рождаемости принята рождаемость гуттеритов.

Источник: [Вишневский 1977: 109, 131].

В религиозно-этническом отношении демографические изменения захватили больше и глубже иудеев, протестантов (немцев, финнов, латышей и эстонцев и др.) и католиков (литовцев, поляков и др.), меньше - православное, исламское, языческое и другое нехристианское сельское население (таблицы 23, 24).

К 1897 г. наилучшие демографические показатели имели лютеране и католики, проживавшие в самых западных регионах империи [Вишневский 1977: 130-134; Марченко 1977: 135-137; Тольц 1977: 138-140]. Надо отметить, что уже в первой половине XIX в. демографическая ситуация в Прибалтике была лучше, чем в остальной России. Хорошие демографические показатели имели также евреи, в некоторых отношениях они были даже лучше, чем у католиков и протестантов: рождаемость у евреев была немного ниже, а брачность, наоборот, выше, внебрачных детей практически не имелось. По средней продолжительности жизни они уступали прибалтийским народам. В середине XIX в. по демографическим показателям евреи мало отличались от православных и мусульман, но к 
концу века они, по-видимому, вступили в стадию демографического перехода от традиционного к современному типу воспроизводства населения.

Таблица 23. Брачное состояние населения различных вероисповеданий в Европейской России без Польши и Финляндии в 1897 г., \%

\begin{tabular}{l|c|c|c|c|c|c|c|c}
\hline \multirow{2}{*}{ Вероисповедание } & \multicolumn{2}{|c|}{ Не состоят в браке } & \multicolumn{2}{c|}{ Состоят в браке } & \multicolumn{2}{c|}{ Вдовые } & \multicolumn{2}{c}{ Разведенные } \\
\cline { 2 - 9 } & мужчины & женщины & мужчины & женщины & мужчины & женщины & мужчины & женщины \\
\hline Православные & 56,0 & 52,1 & 40,3 & 39,4 & 3,7 & 8,4 & 0,03 & 0,04 \\
Католики, лютеране & 61,6 & 56,5 & 35,6 & 34,3 & 2,8 & 9,1 & 0,06 & 0,09 \\
Иудеи & 61,2 & 57,4 & 36,8 & 36,1 & 1,8 & 6,0 & 0,16 & 0,49 \\
Мусульмане & 58,0 & 45,9 & 39,4 & 45,6 & 2,4 & 8,4 & 0,10 & 0,12 \\
В среднем & 57,1 & 52,0 & 39,5 & 39,6 & 3,3 & 8,3 & 0,06 & 0,08 \\
\hline
\end{tabular}

Источник: [Общчий свод... 1905: т.2: ХХХVIII].

\section{Таблица 24. Некоторые демографические характеристики населения различных} вероисповеданий в Европейской России в 1896-1904 гг.

\begin{tabular}{|c|c|c|c|c|c|c|c|}
\hline \multirow{3}{*}{ Вероисповедание } & \multirow{2}{*}{\multicolumn{2}{|c|}{$\begin{array}{c}\text { Возраст } \\
\text { вступления } \\
\text { в брак, лет } \\
\end{array}$}} & \multicolumn{3}{|c|}{ Общие коэффициенты, на 1000} & \multirow{3}{*}{$\begin{array}{c}\text { Смертность } \\
\text { новорожденных } \\
\text { на } 1000 \\
\text { родившихся }\end{array}$} & \multirow{3}{*}{$\begin{array}{c}\text { Доля } \\
\text { внебрачных } \\
\text { детей, \% }\end{array}$} \\
\hline & & & \multirow[t]{2}{*}{ брачности } & \multirow[t]{2}{*}{ рождаемости } & \multirow[t]{2}{*}{ смертности } & & \\
\hline & муж. & жен. & & & & & \\
\hline Православные & 24,2 & 21,3 & 8,7 & 51,1 & 34,8 & 263,0 & 2,4 \\
\hline Католики & 29,1 & 23,3 & 6,9 & 36,5 & 22,3 & 151,0 & 3,4 \\
\hline Протестанты & 28,5 & 24,6 & 6,8 & 29,2 & 21,0 & 161,0 & 3,7 \\
\hline Иудеи & 27,5 & 24,1 & 7,3 & 30,7 & 16,0 & 116,0 & 0,4 \\
\hline Мусульмане & 27,6 & 22,2 & 10,9 & 43,9 & 27,7 & 158,0 & 0,2 \\
\hline В среднем & 25,1 & 21,8 & 8,5 & 50,1 & 30,9 & 224,0 & 2,3 \\
\hline
\end{tabular}

* На 1000 человек.

Источник: [Новосельский 1916а: 26-53].

Мусульмане Европейской России (прежде всего башкиры, волжские и крымские татары) по своим демографическим характеристикам в середине XIX века также мало отличались от православных, но к концу XIX века добились некоторых успехов, так как, с точки зрения демографических характеристик, находились посередине между православными, с одной стороны, католиками и протестантами - с другой. Особенно выгодно они отличались от православных низкой младенческой смертностью [Ершов 1898: 112-116; Материалы по изучению... 1908: 92-97]. Заслуживает внимания, что брачность у мусульман была выше, чем у православных, а рождаемость ниже, что указывает на то, что татары более активно применяли доступные им методы регулирования рождаемости. Мусульмане Средней Азии по своим демографическим показателям намного уступали не только европейским мусульманам, но и православным [Караханов 1977].

Ожидаемая продолжительность жизни для 11 народностей России на 1897 г. хорошо отражает уровень демографического развития каждого из этих этносов (таблица 25).

Таблица 25. Ожидаемая продолжительность жизни при рождении у 11 народностей Европейской России в 1896-1897 гг., лет

\begin{tabular}{l|c|c|c|c|c}
\hline Национальность & Мужчины & Женщины & Национальность & Мужчины & Женщины \\
\hline Русские & 27,5 & 29,8 & Башкиры & 37,2 & 37,3
\end{tabular}




\begin{tabular}{|c|c|c|c|c|c|}
\hline Чуваши & 31,0 & 31,0 & Молдаване & 40,5 & 40,5 \\
\hline Татары & 34,6 & 35,1 & Литовцы & 41,1 & 42,4 \\
\hline Белорусы & 35,5 & 36,8 & Эстонцы & 41,6 & 44,6 \\
\hline Украинцы & 36,3 & 39,9 & Латыши & 43,1 & 46,9 \\
\hline Евреи & 36,6 & 41,4 & В среднем & 31,3 & 33,4 \\
\hline
\end{tabular}

Источник: [Птуха 1928: 37-38].

По этому показателю на первом месте находились латыши, на последнем - русские. Этнические различия в продолжительности жизни обусловливались, во-первых, различной вовлеченностью отдельных народов в демографический переход от традиционного к современному типу воспроизводства населения. Прибалтийские народы и евреи раньше других вступили на этот путь и к концу XIX века достигли значительных успехов под прямым влиянием новых демографических отношений, складывавшихся в Западной Европе, с которой у них были более тесные культурные, религиозные, экономические и другие связи. На рубеже XIX-XX веков Прибалтика во всех отношениях была передовым регионом России. Демографический переход у других этносов начался позже, естественно, они меньшего и добились. Второй фактор, определивший различия в средней продолжительности жизни, можно назвать культурным фактором. От него зависели отношение к детям, качество ухода за ними, уровень санитарии и все другие условия жизни населения, влиявшие на смертность.

\section{РЕВОЛЮЦИЯ ДЕМОГРАФИЧЕСКАЯ И ПОЛИТИЧЕСКАЯ}

Чтобы оценить, насколько режим воспроизводства стал эффективнее, используются три показателя: брутто-коэффициент воспроизводства населения, нетто-коэффициент воспроизводства населения и цена простого воспроизводства (отношение брутто- и неттокоэффициентов), показывающая, сколько девочек надо родить женщине, чтобы обеспечить простое воспроизводство населения или простую замену материнского поколения. Именно это отношение служит мерой экономичности режима воспроизводства, или режима возобновления поколений.

Согласно расчету Е.М. Андреева и А.Г. Вишневского, брутто-коэффициент воспроизводства населения с 1851-1863 по 1904-1913 гг. понизился с 3,261 до 3,089, а неттокоэффициент повысился соответственно с 1,442 до 1,636, цена простого воспроизводства населения понизилась с 2,261 до 1,839 [Воспроизводство населения... 1983: 273]. Следовательно, российская женщина стала меньше рожать, но, несмотря на это, каждое новое материнское поколение становилось более многочисленным. При этом замена одного материнского поколения другим стала проходить на 23\% более эффективно $(2,261: 1,839)$, т.е. с меньшими физическими затратами со стороны женщины и меньшими материальными затратами со стороны родителей. Конечно, это был еще весьма далекий от совершенства режим воспроизводства населения. Такой режим существовал во Франции и Швеции в конце XVIII в. Европейские страны, лежащие к Западу от России, намного опережали ее по демографическому развитию.

Хотя режим воспроизводства населения во второй половине XIX - начале XX века немного рационализировался, он все еще оставался очень неэффективным. На рубеже XIX- 
$\mathrm{XX}$ веков типичная русская женщина в фертильном возрасте (от 16 до 49 лет), вступившая в брак и прожившая с мужем до конца репродуктивного периода (до 49 лет), проводила в девичестве 6 лет, в замужестве - 25 лет, во вдовстве - 2 года, в разводе - 2 недели [Вишневский, Тольц 1988: 93]. Примерно девяти женщинам из десяти приходилось по 8-10 раз рожать, что реально устраняло их из общественной и культурной жизни и сводило по необходимости их существование к беременностям, ухаживанию за детьми, из которых около половины умирало, и к тяжелой работе, поскольку мужчины не могли без их помощи материально обеспечить семью. Например, крестьянка вынуждена была накануне родов до позднего вечера работать в поле, а после родов, которые в 97-98\% случаев проходили либо при помощи деревенских повитух, либо вообще без всякой помощи, уже на третий или четвертый день идти на работу ${ }^{25}$ [Иваницкий 1898: 62; Афиногенов 1903: 3-4]. Случались роды и прямо в поле.

Женщины из городских низов находились примерно в таком же положении. Женщинам из привилегированных слоев также приходилось помногу рожать, хотя они имели медицинскую помощь и послеродовой отдых. Данный режим воспроизводства населения был тяжелым и для мужчин, которые должны были добывать средства на большое число иждивенцев. Каждая трудящаяся семья несла огромные расходы на рождение и выращивание новых поколений, причем эти расходы почти наполовину оказывались бесполезными из-за громадной смертности детей. Эти рациональные и нерациональные затраты задерживали экономический рост страны и препятствовали повышению благосостояния.

Традиционный тип воспроизводства населения с его высокой рождаемостью и смертностью, приносящий людей в жертву продолжению рода человеческого, имел несколько оснований: психологическое - слабое развитие индивидуальности, экономическое - низкий уровень благосостояния, социальное - сословный строй, затруднявший мобильность населения и преодоление социального неравенства, политическое - отсутствие гражданского общества и легальной возможности для осознания и защиты людьми своих интересов, государственное - поддержка государством, политической элитой, научным сообществом и общественностью, заинтересованными в увеличении числа граждан ради повышения военного могущества империи и роста производительных сил общества.

При столь серьезных основаниях изменить традиционный тип воспроизводства населения было чрезвычайно трудно. Это был процесс ломки старых стереотипов, устойчивых традиции, поэтому он растянулся на несколько десятилетий и закончился в Европейской России только в 1950-е годы, когда окончательно завершился переход от традиционного к рациональному, или современному, типу воспроизводства населения. На Западе он закончился на 2-3 поколения раньше [Вишневский 2005; Ливи Баччи 2010].

Демографический переход начался в последней трети XIX века с изменения отношения человека к жизни, смерти, продолжению рода, когда люди в сколько-нибудь значительном числе стали осознавать, что существующее положение вещей ненормально,

${ }^{25}$ Арх. РГО. Разр. 29 (Пермская губерния). Оп. 1. Д. 62, 1855 г. 
что необходимо регулировать рождаемость и уменьшить число детей до разумного. Человек стал рефлексировать, искать средства для улучшения своего положения не вовне (у Бога, царя, властей), как было прежде, а в своем быте, в своих традициях, в себе самом, и нашел их, в том числе, в своем нерациональном демографическом поведении. Демографический переход был тем редким случаем в истории России, когда прогрессивные изменения происходили не по манию царя и не по побуждению властей, а добровольно, сознательно и в индивидуальном порядке, в отдельной семье и потому были необратимыми. Без преувеличения можно сказать: начало демографического перехода было знаковым событием - признаком зарождения новой активной индивидуалистской личности. Чтобы человек мог эффективно контролировать свою сексуальность и рождаемость, ментально и фактически дифференцировать сексуальные, матримониальные и репродуктивные практики (которые в традиционном обществе являлись неразрывным триединством, а в современном обществе - независимыми, направленными на достижение специфических целей), в этом - суть демографического перехода, он должен быть достаточно рациональным и культурно развитым, обладать современным рациональным типом сознания. Это значит быть способным к самосознанию и самоанализу, к адекватной оценке своих личных интересов и мотивов поведения; чувствовать себя субъектом своих действий; стремиться изменить окружающий мир и свою жизнь в соответствии со своими потребностями, целями, идеалами; осуществлять целеполагающую деятельность [Миронов 2015: т.3: 508-509]. Поэтому очевидно, что люди, активно и сознательно вовлеченные в демографический переход, достаточно глубоко изменились психологически, ментально и культурно и потому обладали значительным инновационным потенциалом. Это делало их восприимчивыми ко всем инновациям также и в социальной, политической, культурной, экономической сферах, а также и наиболее подготовленными и желавшими преобразований общественной жизни.

Однако, как мы видели, сколько-нибудь заметно демографический переход охватил незначительную часть населения. Если к вовлеченным в него отнести всех протестантов, католиков и иудеев обоего пола, а также лиц с высшим и средним образованием среди православных, мусульман и других нехристианских вероисповеданий мужского пола, то их совокупная доля в 1897 г. составляла в Европейской России (без Польши и Финляндии) около 14\% и к 1917 г. практически не изменилась [Общий свод... 1905: т.1: XV, XVIII; Брук, Кабузан 1980: 74-93; Миронов 2012: 587]. Это, вероятно, преувеличенная оценка, максимум максиморум. Четырнадцать процентов населения, вовлеченного в демографическую революцию, означало, что народ в массе не был готов к последовательным буржуазнодемократическим реформам. Восемьдесят шесть процентов населения более сочувствовали эсеровской, большевистской или анархистской программам восстания, бунта, экспроприаций, устранения несогласных и построения рая на Земле здесь и сейчас. Но давно замечено: кто хочет всего и сразу, тот не получает ничего. Революция 1917 г. произошла преждевременно и не реализовала цели, которые первоначально ставили ее либерально-демократические лидеры и организаторы. Подавляющее большинство населения еще было не готово им следовать. «Деревня живет естественноживотной жизнью», - писал известный этнограф о российской деревенской глубинке начала 1920-х годов М.Я. Феноменов [Феноменов 1925: 1: 91], имея в виду воспроизводство населения. 
Но этот вывод с некоторыми ограничениями можно распространить и на другие сферы жизни.

В частности, в России движение за эмансипацию женщин (феминизм), начавшись на рубеже 1850-1860-х годов, в отличие от Запада, не получило широкого распространения [Кечеджи-Шаповалов 1902: 132-203; Крадецкая 2012; Новикова 2000: 1-28; Стайтс 2004; Тишкин 1995; Юкина 2007: 459-466; Edmondson 1984; Stites 1991]. На момент его апогея в 1905 г. в нем участвовало только около 10 тыс. человек, в то время как в США - более 100 тыс., в Дании - около 80 тыс. [Стайтс 2004: 309-322], с учетом численности населения - в десятки раз больше.

Внутрисемейные отношения у огромного большинства населения к 1917 г. оставались авторитарно-патриархальными. Они строились на доминировании мужчин, на иерархии, строгом разделении ролей по половозрастному признаку, приоритете общих семейных интересов над индивидуальными, включенности семей в жизнь сословных корпораций, которые оказывали влияние на внутрисемейные отношения. Политические антропологи указывают на зависимость политического режима от типа семейных отношений [Бочаров 2007, 2: 203-217]. Преобладание патриархально-авторитарных отношений в семьях всех сословий поддерживало политический абсолютизм в государстве по той причине, что авторитарные семьи воспитывали в людях черты авторитарной личности: пассивность, конформизм, ригидность мысли, склонность к стереотипам, отсутствие критической рефлексии, сексуальное подавление, страх и отвращение ко всему новому, непохожему и девиантному [Адорно 2001: 20, 281-285], - а такие люди становились благодатной социальной базой для авторитарных отношений во всех сферах общественной жизни со всеми вытекающими из этого политическими, экономическими и социальными последствиями.

Таким образом, в результате демографической модернизации в позднеимперской России произошла известная рационализация демографического поведения у значительной части населения, улучшились демографические показатели, несколько повысилась эффективность воспроизводства населения, гуманизировались внутрисемейные отношения. Не менее важно - началась дифференциация сексуального, матримониального и репродуктивного поведения и получил развитие достаточно эффективный индивидуальный контроль над рождаемостью, что в демографии рассматривается в качестве критериев качественных модернизационных изменений в процессе воспроизводства населения [Захаров 2003: 19-21].

Однако наблюдавшиеся позитивные перемены объяснись главным образом тем, что в демографический переход включились около 14\% российских граждан, в основном из числа образованных и состоятельных людей, проживавших в больших городах, а также жителей западных регионов - по вероисповеданию иудеев, католиков и протестантов. 86\% населения (преобладающая часть сельского и городского населения православного, мусульманского, языческого и других нехристианских вероисповеданий) оказалось затронутым новыми веяниями весьма поверхностно. Людей, активно и сознательно вовлеченных в демографический переход (демографических девиантов, с точки зрения поведенческих и культурных стандартов конца XIX-начала XX века), можно считать 
инновационным человеческим капиталом страны. Он был значительным и необходимым для медленной и постепенной всеобъемлющей модернизации страны, но не достаточным для быстрых и глубоких революционных буржуазно-демократических преобразований. Революция 1917 г. оказалась преждевременной. Политические акушеры поторопились и искусственно ускорили рождение новой России. Но новорожденный оказался недоношенным. В результате революция не смогла решить задачи, которые ставили ее лидеры и организаторы.

\section{БЛАГОДАРНОСТИ}

Пользуюсь случаем, чтобы выразить благодарность двум анонимным рецензентам за ценные замечания, высказанные по первому варианту статьи.

\section{ЛИТЕРАТУРА}

Авдеев А. (2008). Младенческая смертность и история охраны материнства и детства в России и СССР // Демографические исследования. 14. Историческая демография / М.Б. Денисенко, И. А. Троицкая (ред.). М.: МАКС Пресс: 14-73.

Адорно Т. (2001). Исследование авторитарной личности. М.: Серебряные нити. 416 с.

Афиногенов А.О. (1903). Жизнь женского населения Рязанского уезда в период детородной деятельности женщины. СПб. 136 с.

Багалей Д.И., Д.П. Миллер (1912). История города Харькова за 250 лет его существования (с 1655 по 1905 г.). Т.2. Харьков: Издательство Харьковского городского общественного управления. $986 \mathrm{c.}$

Балов А.В. (1898). Очерки Пошехонья. Оттиск из журнала «Этнографическое обозрение». M.: $1-20$.

Безгин В.Б. (2004). Крестьянская повседневность (традиция конца XIX-начала XX в.). М.; Тамбов: МПГУ Издательство ТГТУ. 303 с.

Беллин Э.Ф. (1889). Отравления азотной кислотой в связи с систематическим употреблением ее для целей плодоизгнания // Вестник общественной гигиены, судебной и практической медицины. 1 (1): 20-36.

Белякова Е. В. (2002). «Бабьи стоны»: Как разводились в Российской империи // Родина. 7: 63-67.

Бечаснов П. (1893). Статистические данные о разводах и недействительных браках за 1867-1886 гг. (по епархиям Европейской России). СПб.: Центральный статистический комитет Министерства внутренних дел. 33 с.

Бобровский П. (1863). Гродненская губерния: в 2 т. 1. СПб.: Типография Департамента Генерального штаба. 138 с.

Боряковский А.Г. (1893). О вреде средств, препятствующих зачатию // Врач. 32: 886-887.

Бочаров В.В. (2007). Иррациональность и власть в политической культуре России // Антропология власти. Хрестоматия по политической антропологии: в 2 т. / Под ред. В.В. Бочарова. СПб.: Изд-во С.-Петербургского университета. 2: 203-217. 
Боярский А.Я. (1975). Население и методы его изучения. М.: Статистика: 225-238.

Брук С.И., В.М. Кабузан (1980). Динамика этнического состава населения России в эпоху империализма (конец XIX-1917 г.) // История СССР. 3: 74-93.

Булгакова Л.А. (2008). Внебрачная рождаемость в дореволюционной России (К вопросу об одной демографической загадке) // Страницы истории. Сб. науч. статей, посвященных 65-летию проф. Г.А. Тишкина / Под ред. Р.Ш. Ганелина. СПб.: Издательский Дом Санкт-Петербургского университета: 367-380.

Булгакова Л.А. (2009). Невенчанные солдатки: борьба за признание // Власть, общество и реформы в России в XIX-начале XX века: исслед., историография, источниковедение. Антология / Под ред. А.Н. Цамутали. СПб.: Олеариус Пресс: 183-214.

Бушнелл Дж. (2011). Половое воздержание и целибат в приходе Купля Гороховецкого уезда Владимирской губернии в 1750-е-1830-е гг. // Старообрядчество: История; Культура; Современность. Материалы X Междунар. науч.-практ. конф.: в 2 т. 2. URL: http://www.borovskold.ru/content.php?page=lonuemcd_rus\&id=115 (дата обращения: 05.10.2017).

Быт великорусских крестьян-землепашцев (1993). Описание материалов Этнографического бюро князя В.Н. Тенишева (на примере Владимирской губернии) / Авторы-составители Б.М. Фирсов, И.Г. Киселева. СПб.: Издательство Европейского Дома. $471 \mathrm{c}$

Ван-дер-Борн Р. (1909). Избежание материнства в связи с гигиеной брака, с точки зрения современной медицины. СПб.: Типография товарищества «Грамотность». 144 с.

Веременко В.А. (2007). Дворянская семья и государственная политика России (вторая половина XIX-XX в.). СПб.: Европейский дом. 622 с.

Вигдорчик Н.А. (1914). Детская смертность среди петербургских рабочих // Общественный врач. 2: 212-253.

Вишневский А. Г. (1977). Ранние этапы становления нового типа рождаемости в России // Брачность, рождаемость, смертность в России и в СССР / Под ред. А.Г. Вишневского. М.: Статистика: 105-135.

Вишневский А. Г. (2005). Демографическая революция // Вишневский А.Г. Избранные демографические труды. М.: Наука. 1: 5-216.

Вишневский А.Г., М.С. Тольц (1988). Эволюция брачности и рождаемости в советский период // Население СССР за 70 лет / Под ред. Л.Л. Рыбаковского. М.: Наука: 75-114.

Владимирский-Буданов М.Ф. (1900). Обзор истории русского права. Киев; СПб.: Н.Я. Голобин. 674 с.

Военно-статистический сборник (1871). 4. Россия. 1. / Под ред. Н.Н. Обручева. СПб.: Военная типография 922 с.

Войцеховский А.И. (1888). Об одном народном абортивном средстве // Протоколы и труды общества елисаветградских врачей за 1886-1887 гг. СПб. 37-41.

Воспроизводство населения СССР (1983) / Под ред. А.Г. Вишневского, А.Г. Волкова. М.: Финансы и статистика. 303 с.

Всеподданнейший отчет обер-прокурора Святейшего Синода по ведомству православного исповедания за 1842-1914 год (1842-1914). СПб.: Синодальная типография. 
Всеподданнейший отчет обер-прокурора Святейшего Синода по ведомству православного исповедания за 1913, 1914 год (1915). СПб.: Синодальная типография. 142 с.

Гернет М.Н. (1911). Детоубийство: социологическое и сравнительно-юридическое исследование. М.: Типография Императорского Московского университета. 318 с.

Гернет М.Н. (1916). Истребление плода с уголовно-социологической точки зрения // Отчет Х общего собрания Русской группы Международного союза криминалистов 13-16 февраля 1914 г. в Петербурге. Пг.: 233-277.

Гиляровский Ф.В. (1866). Исследование о рождении и смертности детей в Новгородской губернии. СПб.: Типография К. Вульфа. 664 с.

Голод С.И. (1996). ХХ век и тенденции сексуальных отношений в России. СПб.: Алетейя. $191 \mathrm{c.}$

Города России в 1910 году (1914). СПб.: типография Н.Л. Ныркина. 1200 с.

Двенадцатый съезд Общества русских врачей в память Н.И. Пирогова (1913). Вып. 2. СПб. $109 \mathrm{c}$.

Движение населения в Европейской России по группам губерний (1865). 1861-1865. 5 с.

Движение населения в Российской империи за 1867 год (1872). СПб.: Типография

Движение населения в Российской империи за 1910 год (1916). Петроград: Типография Штаба Петроградского военного округа. 251 с.

Демографическая модернизация России (2006) / Под ред. А.Г. Вишневского. М.: Новое издательство. 599 с.

Денисенко М.Б., Ж.П. Далла Зуанна (2001). Сексуальное поведение российской молодежи // Социологические исследования. 2: 83-87.

Дрекслер К.И. (1929). Предохранительные средства в современном браке или как предохранить себя от беременности, не прибегая к аборту (1929). Минск: Автор. 103 с.

Дьячков В.Л. (2003). Факторы брачно-семейного поведения женщин в XX в. в зеркале устной истории // Женская повседневность в России в XVIII-XX вв. Материалы междунар. науч. конф., 25 сентября / Под ред. П.П. Щербинина. Тамбов: Изд-во ТГУ. $206-214$.

Ершов С. (1898). Материалы для санитарной статистики Свияжского уезда: Опыт сравнительной демографии русской и татарской народностей. СПб.: Типография Яблонского и Перотт. 197 с.

Жбанков Д.Н. (1922). О половой жизни учащихся женщин // Врачебное дело. 10/12.

Заболотная Л.П. (2010). Имели ли женщины право на развод в Молдове XVI-XVII вв.? // Социальная история. Ежегодник 2009. М.: Алетейя: 9-22.

Захаров С.В. (2002). Рождаемость в России: первый и второй демографический переход // Демографическая модернизация, частная жизнь и идентичность в России. Тезисы докладов. Научная конференция. Москва, 27-28 февраля. М.: ЦДЭЧ ИНП РАН, Институт этнологии и антропологии РАН: 19-26.

Захаров С.В. (2003). Демографический переход и воспроизводство поколений в России // Вопросы статистики. 11: 3-12.

Иванилова Е.П. (2002). Проблема существования гражданских браков в Тамбовской губернии, XIX в. // Социальная история российской провинции в контексте 
модернизации аграрного общества в XVII-XX вв. Материалы междунар. конф., май / Под ред. В.В. Канищева. Тамбов: Издательство ТГУ: 127-129.

Иваницкий Н. (1898). Сольвычегодский крестьянин, обстановка его жизни и деятельность // Живая старина. 1 (8): 3-74.

Историко-статистические таблицы по Ярославской губернии за 1862-1898 гг. (1901). Ярославль: Типография Губернской земской управы. 87 с.

Караханов М.К. (1977). Демографические процессы в Средней Азии во второй половине XIX столетия // Брачность, рождаемость, смертность в России и в СССР / Под ред. А.Г. Вишневского. М.: Статистика: 191-213.

Кечеджи-Шаповалов М.В. (1902). Женское движение в России и за границей. СПб.: Типография Е. Евдокимова. 210 с.

Кон И.С. (1990). Введение в сексологию. М.: Медицина. 336 с.

Кон И.С. (1997). Сексуальная культура в России: Клубничка на березке. М.: О.Г.И. 460 с.

Котлова Т.Б. (2002). Замужество и развод в жизни горожанки на рубеже XIX-XX вв. (по материалам центральных губерний России) // Адам и Ева. 3: 154-172.

Крадецкая С.В. (2012). Гражданская идентичность феминисток в России в начале XX в.: дисс. ... канд. ист. наук. М. 329 с.

Крюкова С.С. (1992). Брачные традиции южнорусских губерний во II пол. XIX в. // Этнографическое обозрение. 4: 41-50.

Кулишер E.M. (1916). Наказуемость аборта. Отчет Х общего собрания Русской группы Международного союза криминалистов 13-16 февраля 1914 г. в Петербурге. Пг.: 245255.

Лаптев М. (1861). Казанская губерния. СПб.: Военная типография. 616 с.

Латкин В.Н. (1909). Учебник истории русского права периода империи: (XVIII и XIX ст.). СПб.: Типография Монтвида. 644 с.

Лебина Н. (2007). «Навстречу многочисленным заявлениям трудящихся женщин...»: Абортная политика как зеркало советской социальной заботы // Советская социальная политика 1920-х—1930-х годов: идеология и повседневность / Под ред. П. Романова, Е. Ярской-Смирновой. М.: Вариант: 228-241.

Лещенко В.Ю. (2004). Русская семья (XI-XIX вв.). СПб.: СПГУТД. 607 с.

Ливи Баччи М. (2010). Демографическая история Европы. СПб.: Alexandria. 298 с.

Липинский А. И. (1868). Симбирская губернияв: в 2 частях. 2. СПб.: Военная типография. $761 \mathrm{c}$.

Луканин А. (1878). Население Оханского уезда Пермской губернии по сословиям, возрастам и семейному составу // Записки Русского географического общества по отделению статистики. 5. СПб.: Типография В. Киршбаума.

Максимова Т.О. (1998). Развод по-русски // Родина. 9: 55-60.

Мареева Е.П. (2001). Мужчины и женщины при заключении и расторжении брака в XIX в. (по материалам Тамбовской епархии) // От мужских и женских к гендерным исследованиям. Материалы междунар. науч. конф., 20 апреля / Под ред. П.П. Щербинина. Тамбов: Издательство ТГУ: 38-42. 
Мареева Е.П. (2003). Проблема получения женщинами права на отдельное от супруга проживание (на материалах Тамбовской губернии, XIX-начало XX в.) // Женская повседневность в России в XVIII-XX вв. Материалы международной научной конференции, 25 сентября / Под ред. П.П. Щербинина. Тамбов: Издательство ТГУ: 33 37.

Марченко О.В. (1977). Индексы рождаемости по 50 губерниям Европейской России в конце XIX в. // Брачность, рождаемость, смертность в России и в СССР / Под ред. А.Г. Вишневского. М.: Статистика: 128-137.

Материалы по изучению детской смертности в Саратовской губернии с 1902 по 1904 г. (1908). В 3 вып. 2 / Сост. Н.И. Тезяков. Саратов: Саратовское губернское земство. $285 \mathrm{c}$.

Мельцин М.O. (1999). Судьбы старинного российского дворянства в конце XVIII-начале XX века: Князья Долгоруковы в системе общественных отношений: дисс. ... канд. ист. наук. СПб. 348 с.

Милютин В. (1946). Избранные произведения. М.: Государственное издательство политической литературы. 448 с.

Минх А.Х. (1890). Народные обычаи, суеверия, предрассудки и обряды крестьян Саратовской губернии. СПб.: Типография В. Безобразова и К․ 152 с.

Миронов Б.Н. (1990). Русский город в 1740-1860-е годы: Демографическое, социальное и экономическое развитие. Л.: Наука. 271 с.

Миронов Б.Н. (1991). История в цифрах. Л.: Наука. 165 с.

Миронов Б.Н. (2012). Благосостояние населения и революции в имперской России, XVIIIначало XX века. М.: Весь мир. 844 с.

Миронов Б.Н. (2014). Российская империя: от традиции к модерну: в 3 т. 1. СПб.: Дмитрий Буланин. 896 с.

Миронов Б.Н. (2015). Российская империя: от традиции к модерну: в 3 т. 3. СПб.: Дмитрий Буланин. 992 с.

Михайлов В.М. (1895). Средние русские акушерские итоги за пятьдесят лет по материалам печатных отчетов родовспомогательных учреждений, 1840-1890. Новгород: Типография И.И. Игнатовского. 448 с.

Моисеенко Т.Л. (1984). Методы изучения внутрисемейного контроля над рождаемостью : (обзор) // Демография западноевропейского Средневековья в современной зарубежной историографии : K XVI Международному конгрессу исторических наук (Штутгарт, 1985). Реферативный сборник. М.: ИНИОН: 73-86.

Мухина 3.3. (2012). Плодоизгнание и контрацепция в традиционной крестьянской культуре Европейской России (вторая половина XIX-30-е гг. XXв.) // Этнографическое обозрение. 3: 147-160.

Никологорский С.А. (2012). Семейный вопрос в российской публицистике конца XIXначала XX века: Автореф. ... канд. ист. наук. М.: Московский госуарственный университет им. М.В. Ломоносова. 30 с.

Новикова Н. (2000). Либеральный феминизм в России и на Западе: опыт сравнительного анализа. URL: www.kennan.yar.ru/seminars/novikova-24102000.html (дата обращения: 01.10.2017). 
Новосельский С.А. (1914). К вопросу о понижении смертности и рождаемости в России. СПб: Типография МВД. 16 с.

Новосельский С.А. (1916а). Обзор главнейших данных по демографии и санитарной статистике России // Календарь для врачей всех ведомств на 1916 год: в 2 ч. Ч. 2. СПб.: К.Л. Рикер: 14-93.

Новосельский С.А. (1916b). Смертность и продолжительность жизни в России. Пг.: Типография Министерства внутренних дел. 208 с.

Новосельский С.А. (1978). Демография и статистика: избранные произведения. М.: Статистика. 269 с.

О составе и движении населения по губерниям Нижегородской и Ярославской (1861). СПб.: Типография С.Н. Бекенева. 105 с.

Общий свод по империи результатов разработки данных Первой всеобщей переписи населения, произведенной 28 января 1897 г. (1905). В 2 т. / Под ред. Н.А. Тройницкого. СПб.: Н.Л. Ныркин.

Отчет Х общего собрания Русской группы Международного союза криминалистов 13-16 февраля 1914 г. в Петербурге (1916). Пг. 400 с.

Отчет Министерства юстиции за 1834-1840 год (1835-1841). СПб.: Типография Правительствующего Сената.

Памятная книжка Воронежской губернии на 1861 год (1861). Воронеж: Типография В. Гольдштейна. 358 с.

Памятная книжка Воронежской губернии на 1870-71 год (1871). Воронеж: Типография В. Гольдштейна. 346 с.

Перепись Москвы 1902 года (1904). В 4 вып. 1. Население. 1. Население по полу, возрасту, месторождению, продолжительности пребывания в Москве, семейному состоянию, сословиям, грамотности и степени образования. М.: Статистическое отделение Московской городской управы. 155 с.

Петроград по переписи населения 15 декабря 1910 года: население (1915). В 2 ч. / Под ред. управляющего отделением В.В. Степанова. 1. Петроград: Издание Городской управы по Статистическому отделению. 339 с.

Пилсудский Б. (1910). Роды, беременность, выкидыши, близнецы, уроды, бесплодие и плодовитость у туземцев острова Сахалина // Живая старина. 73-74. I-II: 22-48.

Попов А.А. (1994). Краткая история аборта и демографической политики в России // Планирование семьи в Европе. 1: 5-7.

Попов Г.И. (1903). Русская народно-бытовая медицина: По материалам этнографического бюро кн. В.Н. Тенишева. СПб.: Типография А.С. Суворина. 404 с.

Попроцкий М. (1864). Калужская губерния. В 2 т. 1. СПб.: Типография Э. Веймара. 706 с.

Преображенский И. (1901). Отечественная церковь по статистическим данным с 1840-41 по 1890-91 гг. СПб.: Типография Е. Евдокимова. 236 с.

Птуха М. (1928). Смертность 11 народностей Европейской России в конце XIX века. Киев: ЦСУ Украины. 56 с.

Рабинович М.Г. (1978). Очерки этнографии русского феодального города: Горожане, их общественный и домашний быт. М.: Наука. 328 с. 
Рашин А.Г. (1956). Население России за 100 лет (1811-1913 гг.). Статистические очерки. М.: Госстатиздат. 352 с.

Розанов Н.П. (2004). Воспоминания старого москвича. М.: Русскій міръ. 429 с.

Роледер Г. (1909). Как предупредить беременность (пер. с нем.). М.: Типография С.П. Семенова. 87 с.

Русские крестьяне. Жизнь. Быт. Нравы (2004-2017). Материалы «Этнографического бюро» князя В.Н. Тенишева. 1. Костромская и Тверская губернии. 2. Ярославская губерния. 3. Калужская губерния. 4. Нижегородская губерния. 5. Вологодская губерния. 6. Курская, Московская, Олонецкая, Псковская, Санкт-Петербургская и Тульская губернии. 7. Новгородская губерния. 9. Казанская губерния. Спасский и Лаишевский уезды. СПб: Деловая полиграфия.

Садвокасова Е.А. (1969). Социально-гигиенические аспекты регулирования размеров семьи. М.: Медицина. 191 с.

Санкт-Петербург (1868). Санкт-Петербург: исследования по истории, топографии и статистике столицы (1868). В 3 т. Т. 1. СПб.: Типография В. Безобразова. 207 с.

Сборник сведений по России за 1884-1885 гг. (1887). СПб.: Центральный статистический комитет Министерсва внутренних дел. 295 с.

Сборник статистико-экономических сведений по сельскому хозяйству России и иностранных государств (1917). Год девятый. Пг.: Типография И.Ф. Вайсберга. 649 с.

Свод законов Российской империи (1857). Х. 1. Законы гражданские. СПб.: Второе отделение собственной его императорского величества канцелярии. 491, 104 с.

Свод статистических сведений по делам уголовным, произведенным в 1873, 1892, 1913 году $(1875,1896,1916)$. СПб.: Министерство юстиции.

Семенов Ю.И. (1996). Пережитки первобытных форм отношения полов в обычаях русских крестьян XIX-начала XX в. // Этнографическое обозрение. 1: 39-46.

Семенова-Тян-Шанская О.П. (1914). Жизнь «Ивана»: очерки из быта крестьян одной из черноземных губерний. СПб.: Типография М.М. Стасюлевича. 135 с.

Синкевич Г.П. (1929). Вологодская крестьянка и ее ребенок. М.; Л.: Государственное медицинское издательство. 90 с.

Сифман Р.И. (1977). Динамика численности населения России за 1897-1914 гг. // Брачность, рождаемость, семья в России и в СССР / Под ред. А.Г. Вишневского. М.: Статистика: 62-82.

Стайтс Р. (2004). Женское освободительное движение в России: Феминизм, нигилизм и большевизм, 1860-1930. М.: Росспэн. 616 с.

Сталь Н.Е (1867). Пензенская губерния. В 2 ч. 2. СПб.: Типография Бургеля. 469 с.

Статистический ежегодник России 1914 г. (1915). II. Пг.: Типография Штаба Петроградского военного округа. 119 с.

Статистический ежегодник России 1915 г. (1916). II. Пг.: ЦСК. 58 с.

Статистический ежегодник России 1916 г. (1918). Вып. 1. М.: Типография Московского Совета рабочих, солдатских и крестьянских депутатов. 90 с.

Статистический ежегодник С.-Петербурга за 1901-1902 гг. (1905). СПб.: С.Петербургская городская типография. $761 \mathrm{c.}$ 
Тихонов В.П. (1891). Материалы для изучения обычного права среди крестьян Сарапульского уезда Вятской губернии // Сборник сведений для изучения быта крестьянского населения России. 3 / Под ред. Н. Харузина. М.: Типография А. Левенсон и К. 146 с.

Тишкин Г.А. (1995). Женский вопрос в истории России // Феминизм и российская культура / Под ред. Г.А. Тишкина. СПб.: СПбГАК: 138-167.

Тольц М.С. (1977). Брачность населения России в конце XIX-начале XX в. // Брачность, рождаемость, смертность в России и в СССР / Под ред. А.Г. Вишневского. М.: Статистика: 138-153.

Томилин С.А. (1987). К вопросу о плодовитости крестьянки и влиянии ее на детскую смертность // Советская демография за 70 лет / Под ред. Т.В. Рябушкина. М.: Наука: 107-109.

Третий съезд Общества русских врачей в память Н.И. Пирогова в С.-Петербурге (3-10 января 1889 г.): полный отчет (1889). СПб. 441 с.

Трубников В.В. (1858). Результаты народных переписей в Ардатовском уезде Симбирской губернии // Сборник статистических сведений о России, издаваемый РГО. 3. СПб.: Типография Морского министерства: 343-427.

Успенский Г.И. (1954). Полное собрание сочинений: в 14 т. 8. М.: Издательство Академии наук СССР. 647 c.

Фавр В.В. (1910). К вопросу о половых сношениях, о венерических болезнях и онанизме учащейся молодежи: результаты харьковской анкеты среди студентов. Харьков: Типография «Печатное дело»: 1-19.

Федоров В.А. (1994). Мать и дитя в русской деревне (конец XIX-начало XX в.) // Вестник Московского университета. Серия 8: История. 4: 3-21.

Феноменов М.Я. (1925). Современная деревня: Опыт краеведческого обследования одной деревни (деревня Гадыши, Валдайского уезда, Новгородской губернии). 2. М.; Л.: Государственное издательство. 211 с.

Фриз Г. (2009). Мирские нарративы. о священном таинстве: брак и развод в позднеимперской России // Православие: Конфессия, институты, религиозность (XVII-XX вв.). Сборник статей / Под ред. М. Долбилова, П. Рогозного. СПб.: Издательство Европейского университета в Санкт-Петербурге: 122-175.

Ханыков Я.В. (1851). Очерк истории медицинской полиции в России. СПб.: Типография Министерства внутренних дел. 114 с.

Хлопин Г., И. Эрисман (1899). Медицина и народное здравие // Энциклопедический словарь / Под ред. Ф.А. Брокгауза, И.А. Ефрона. 27-а: Россия. СПб.: Типография Акционерного общества «Издательское дело»: 214-227.

Цатурова М.К. (2011). Три века русского развода (XVI-XVIII века). М.: Логос. 285 с.

Членов М.А. (1907). Половая перепись московского студенчества // Русский врач. 31-32: 1072-1111.

Чухнин П.Н. (1894). К статистике выкидышей и преждевременных родов среди народонаселения России // Труды пятого съезда Общества русских врачей в память Н.И. Пирогова. В 2 т. 1. СПб. XCIV, 712, 51 с.

Щербинин П.П. (2002). Незаконнорожденные дети в семьях солдаток в XVIII-XIX вв. // Социальная история российской провинции в контексте модернизации аграрного 
общества в XVII-XX вв. Материалы международной конференции (май 2002) / В.В. Канищев (ред). Тамбов: Издательство ТГУ: 142-146.

Щербинин П.П. (2004). Военный фактор в повседневной жизни русской женщины в XVIII-начале XX в. Тамбов: Юлис. 507 с.

Юкина И.И. (2007). Русский феминизм как вызов современности. СПб.: Алетейя Историческая книга. 539 с.

Яковлев Я. (1923). Деревня как она есть. М.: Красная новь. 132 с.

Яковлев Я. (1924). Наша деревня: Новое в старом и старое в новом. М.: Красная новь. $180 \mathrm{c}$.

Bridger S. (1992). Soviet Rural Women: employment and family life // Russian peasant women / B. Farnsworth, L. Viola, eds. New York: Oxford university press: 271-293.

Edmondson L.H. (1984). The feminist movement in Russia: 1900-1917. Stanford, CA: Stanford university press. $351 \mathrm{p}$.

Engelstein L. (1991). Abortion and the civic order: the legal and medical debates // Russian's women: accommodation, resistance, transformation / B.E. Clements, B.A. Engel, Ch. D. Worobec, eds. Berkeley, CA et al.: University of California press: 185-207.

Engelstein L. (1992). The keys to happiness: sex and the search for modernity in fin-de-siècle Russia. Ithaca; London: Cornell university press. $480 \mathrm{p}$.

Farnsworth B. (1992). Rural women and the law: divorce and property rights in the 1920's, beatrice // Russian peasant women / B. Farnsworth, L. Viola, eds. New York: Oxford university press: $167-188$.

Freeze G.L. (1990). Bringing order to the Russian family: marriage and divorce in Imperial Russia, 1760-1860 // The journal of modern history. 62 (4): 709-746.

Freeze G.L. (2006). Matrimonial sacrament and profane stories: class, gender, confession, and the politics of divorce in late Imperial Russia // Sacred stories: religion and spirituality in modern Russia / M. Steinberg, H. Coleman, eds. Bloomington, Indiana: Indiana university press: $146-178$.

Hajnal J. (1965). European marriage patterns in perspective // Population in history / D.D. Glass, D.E.C. Eversley, eds. London : Edward Arnold publishers: 101-143.

McLaren A. (1990). A history of contraception from antiquity to the present. Oxford, UK ; Cambridge, Mass., USA: B. Blackwell. 275 p.

Patterns of first marriage: timing and prevalence (1990). New York: United Nations. 327 p.

Ransel D. (1982). Problems in measuring illegitimacy in prerevolutionary Russia // Journal of social history Carnegie-Mellon university. 16 (2): 11-27.

Ransel D.L. (1988). Mothers of misery: child abandonment in Russia. Princeton, NJ: Princeton university press. $300 \mathrm{p}$.

Ransel D.L. (2000). Village mothers: three generations of change in Russia and Tataria. Bloomington and Indianapolis: Indiana university press. $314 \mathrm{p}$.

Riddle J.M. (1997). Eve's herbs: a history of contraception and abortion in the West. Cambridge, Mass.: Harvard university press. 352 p.

Riddle J.M. (2001). Birth, contraception, and abortion // Encyclopedia of European social history from 1350 to 2000. In 6 vols. 2 / P. Stearns, ed. New York etc. : Charles Scribner's Sons: $181-191$ 
Stites R. (1991). The women's liberation movement in Russia: feminism, nihilism, and bolshevism, 1860-1930. Princeton: Princeton university press. 464 p. 


\title{
THE RUSSIAN REVOLUTION OF 1917 THROUGH THE PRISM OF DEMOGRAPHIC MODERNIZATION
}

\section{BORIS MIRONOV}

\begin{abstract}
In late imperial Russia demographic indicators improved, the efficiency of population replacement increased somewhat, the familiar rationalization of demographic behavior occurred, and intra-familial relations were humanized. But arguably most important were the differentiation of sexual, matrimonial, and reproductive behavior among a significant portion of the population and the development of individual control over fertility, changes regarded in demography as criteria for the first demographic transition. The primary explanation of these observed positive changes lies in the participation in this demographic revolution of approximately 14 percent of Russian citizens, mainly from the educated and affluent population living in large cities, as well as residents of the western regions who were Jews, Catholics, and Protestants by confession. The predominant portion of the rural and urban population, of Orthodox, Muslim, pagan, and other non-Christian religious affiliations (approximately 86 percent of the entire population), was affected by the new trends superficially. People actively and consciously drawn into the demographic transition, having been transformed psychologically, mentally, and culturally, also displayed receptivity to innovations in the social, political, cultural, and economic spheres and were the most prepared for and desirous of the refashioning of social life on a bourgeois-democratic basis. Their numbers were sufficient for the slow, gradual, overall modernization of the country but inadequate for rapid and profound revolutionary bourgeois-democratic transformations. Consequently, the Revolution of 1917 proved premature. Political midwives hurriedly and artificially hastened the birth of a new Russia. The newborn was born preterm. As a result, the revolution could not meet the challenges set by its leaders and organizers.
\end{abstract}

Key words: nuptiality, fertility, mortality, efficiency of population replacement, birth control, illegitimate children, premarital sex, abortion, contraception, divorce, demographic transition.

Boris N. Mironov (bmironov@mail.wplus.net), St. Petersburg State University, Russia.

DATE RECEIVED: JULY 2017.

\section{REFERENCES}

Adorno T. (2001). Issledovanie avtoritarnoy lichnosti [Research of an authoritarian personality]. Moscow: Serebryanye niti. 416 p.

Afinogenov A.O. (1903). Zhizn' zhenskogo naseleniya Ryazanskogo uezda v period detorodnoy deyatel'nosti zhenshchiny [The life of the female population of the Ryazan uyezd during the fetility period]. Saint Petersburg. 136 p.

Avdeev A. (2008). Mladencheskaya smertnost' i istoriya okhrany materinstva i detstva v Rossii i SSSR [Infant mortality and the history of the protection of motherhood and childhood in Russia and the Soviet Union]. Demograficheskie issledovaniya [Demographic research]. 14. Istoricheskaya demografiya [Historical demography] / M.B. Denisenko, I.A. Troickaja, eds. Moscow: MAKS Press: 14-73.

Bagalej D.I., D.P. Miller (1912). Istoriya goroda Khar'kova za 250 let ego sushchestvovaniya (s 1655 po 1905 g.) [The history of Kharkiv over 250 years of its existence (1655-905)]. T.2. Khar'kov: Izdatel'stvo Khar'kovskogo gorodskogo obshchestvennogo upravleniya. 986 p.

Balov A.V. (1898). Ocherki Poshekhon'ya [Essays of Poshekhonye]. Ottisk iz zhurnala "Etnograficheskoe obozrenie" [Reprint from the journal "Ethnographic review"]. Moscow: $1-20$. 
Bechasnov P. (1893). Statisticheskie dannye o razvodakh i nedeystvitel'nykh brakakh za 1867 1886 gg. (po eparkhiyam Evropeyskoy Rossii) [Statistics on divorces and marriages void for 1867-1886. (dioceses of European Russia)]. Saint Petersburg: Tsentral'nyy statisticheskiy komitet Ministerstva vnutrennikh del. 33 p.

Beljakova E. V. (2002). «Bab'i stony»: Kak razvodilis' v Rossiyskoy imperii ["Indian moaning": divorce in the Russian Empire] // Rodina [Homeland]. 7: 63-67.

Bellin Je.F. (1889). Otravleniya azotnoy kislotoy v svyazi s sistematicheskim upotrebleniem ee dlya tseley plodoizgnaniya [Poisoning nitric acid in connection with the systematic use of it for the purposes of ladojskaya] // Vestnik obshchestvennoy gigieny, sudebnoy i prakticheskoy meditsiny [Bulletin of public hygiene, forensic and practical medicine]. 1 (1): 20-36.

Bezgin V.B. (2004). Krest'yanskaya povsednevnost' (traditsiya kontsa XIX - nachala XX v.) [Peasant daily (the tradition of the late XIX - early XX century)]. Moscow; Tambov: Izdatel'stvo TGTU. 303 p.

Bobrovsky P. (1863). Grodnenskaya guberniya: v 2 t. [Grodno province: in 2 vol.]. 1. Saint Petersburg: Tipografiya Departamenta General'nogo shtaba. 138 p.

Bocharov V.V. (2007). Irratsional'nost' i vlast' v politicheskoy kul'ture Rossii [Irrationality and power in the political culture of Russia] // Antropologiya vlasti [Anthropology of power]. Khrestomatiya po politicheskoy antropologii: $\mathrm{v} 2 \mathrm{t}$. [A reader in political anthropology: in 2 vol] / V.V. Bocharov, ed. Saint Petersburg: Izd-vo Sankt-Peterburgskogo universiteta. 2: 203-217.

Borjakovsky A.G. (1893). O vrede sredstv, prepyatstvuyushchikh zachatiyu [About the dangers of means to prevent conception] // Vrach [Doctor]. 32: 886-887.

Boyarskiy A. I. (1975). Naselenie i metody ego izucheniya [Population and methods of its study]. Moscow: Statistika: 225-238.

Bridger S. (1992). Soviet Rural Women: employment and family life // Russian peasant women / B. Farnsworth, L.Viola, eds. New York: Oxford university press: 271-293.

Bruk S.I., V.M. Kabuzan (1980). Dinamika etnicheskogo sostava naseleniya Rossii v epokhu imperializma (konets XIX-1917 g.) [Dynamics of ethnic composition of the population of Russia in the age of imperialism (late XIX-1917)] // Istoriya SSSR [History of the USSR]. 3: 74-93.

Bulgakova L. A. (2008). Vnebrachnaya rozhdaemost' v dorevolyutsionnoy Rossii (K voprosu ob odnoy demograficheskoy zagadke) [Extra-marital fertility in pre-revolutionary Russia (To the question about a demographic mystery)] // Stranitsy istorii [Pages of history]. Cb. nauch. statey, posvyashchennykh 65-letiyu prof. G.A. Tishkina [Volume of scientific articles, dedicated to the 65th anniversary of Professor G.A. Tishkin] / R.Sh. Ganelina, ed. Saint Petersburg: Izdatel'skiy Dom Sankt-Peterburgskogo universiteta: 367-380.

Bulgakova L.A. (2009). Nevenchannye soldatki: bor'ba za priznanie [Unwed wives of soldiers: the struggle for recognition] // Vlast', obshchestvo i reformy v Rossii v XIX-nachale XX veka: issled., istoriografiya, istochnikovedenie [Government, society and reforms in Russia in XIX-early XX centuries: studies., historiography, source studies]. Antologiya [Anthology] / A.N. Camutali, ed. Saint Petersburg: Olearius Press: 183-214.

Bushnell Dzh. (2011). Polovoe vozderzhanie i tselibat v prikhode Kuplya Gorokhovetskogo uezda Vladimirskoy gubernii v 1750-e-1830-e gg. [Sexual abstinence and celibacy in the parish Purchase, Gorokhovets district of the Vladimir province in 1750 - 1830] // Staroobryadchestvo: Istoriya; Kul'tura; Sovremennost' [Old Believers : History ; Culture]. 
Materialy X Mezhdunar. nauch.-prakt. konf. [Materials of the Xth Intern. scientific-practical conference]. V 2 t. [In 2 vol.]. 2. URL:

http://www.borovskold.ru/content.php?page=lonuemcd_rus\&id=115 (accessed: 05.10.2017).

Byt velikorusskikh krest'yan-zemlepashtsev [The life of the Great Russian peasants-tillers]

(1993). Opisanie materialov Etnograficheskogo byuro knyazya V.N. Tenisheva (na primere

Vladimirskoy gubernii) [Description of materials of Ethnographic Bureau of Prince V.N.

Tenisheva (on the example of the Vladimir province)] / B.M. Firsov, I.G. Kiseleva, authoreds. Saint Petersburg: Izdatel'stvo Evropeyskogo Doma. 471 p.

Caturova M.K. (2011). Tri veka russkogo razvoda (XVI-XVIII veka) [Three centuries of Russian divorce (XVI-XVIII century)]. Moscow: Logos. 285 p.

Chlenov M.A. (1907). Polovaya perepis' moskovskogo studenchestva [Sex census of Moscow students] // Russkiy vrach [Russian doctor]. 31-32: 1072-1111.

Chuhnin P.N. (1894). K statistike vykidyshey i prezhdevremennykh rodov sredi narodonaseleniya Rossii [The statistics of miscarriages and premature births among the population of Russia] // Trudy pyatogo s"ezda Obshchestva russkikh vrachey v pamyat' N.I. Pirogova [Proceedings of the fifth Congress of the Society of Russian physicians in memory of N.I. Pirogov]. V 2 t. [In 2 vol.]. 1. Saint Petersburg. XCIV, 712, 51 p.

Demograficheskaya modernizatsiya Rossii [Demographic modernization of Russia, 1900-2000] (2006) / A.G. Vishnevsky, ed. Moscow: Novoe izdatel'stvo. 599 p.

Denisenko M.B., Zh.P. Dalla Zuanna (2001). Seksual'noe povedenie rossiyskoy molodezhi [Sexual behavior of Russian youth] // Sotsiologicheskie issledovaniya [Sociological research]. 2: 83-87.

D'jachkov V.L. (2003). Faktory brachno-semeynogo povedeniya zhenshchin v XX v. v zerkale ustnoy istorii [Factors of marriage and family behavior of women in the twentieth century in the mirror of oral history] // Zhenskaya povsednevnost' v Rossii v XVIII-XX vv. [Women's everyday life in Russia in XVIII-XX centuries]. Materialy mezhdunar. nauch. konf., 25 sentyabrya [Materials of the international scientific conference, September 25] / P.P. Shherbinin, ed. Tambov: Izd-vo TGU. 206-214.

Dreksler K.I. (1929). Predokhranitel'nye sredstva v sovremennom brake ili kak predokhranit' sebya ot beremennosti, ne pribegaya $\mathrm{k}$ abortu [Safety tools in a modern marriage or how to protect themselves from pregnancy without resorting to abortion] (1929). Minsk: Avtor. $103 \mathrm{p}$.

Dvenadtsatyy s`ezd Obshchestva russkikh vrachey v pamyat' N.I. Pirogova [The twelfth Congress of the Society of Russian physicians in memory of N.I. Pirogov] (1913). Vyp. 2 [Vyp. 2]. Saint Petersburg. 109 p.

Dvizhenie naseleniya v Evropeyskoy Rossii po gruppam guberniy [The movement of the population in European Russia by groups of provinces] (1865). 1861-1865. 5 p.

Dvizhenie naseleniya v Rossiyskoy imperii za 1867 god [Population movement in the Russian Empire in 1867] (1872). Saint Petersburg: Tipografiya MVD. 461 p.

Dvizhenie naseleniya v Rossiyskoy imperii za $1910 \operatorname{god}$ [The movement of the population in European Russia in 1910] (1916). Petrograd: Tipografiya Shtaba Petrogradskogo voennogo okruga. $251 \mathrm{p}$.

Edmondson L.H. (1984). The feminist movement in Russia: 1900-1917. Stanford, CA: Stanford university press. $351 \mathrm{p}$. 
Engelstein L. (1991). Abortion and the civic order: the legal and medical debates // Russian's women: accommodation, resistance, transformation / B.E. Clements, B.A. Engel, Ch. D. Worobec, eds. Berkeley, CA et al.: University of California press: 185-207.

Engelstein L. (1992). The keys to happiness: sex and the search for modernity in fin-de-siècle Russia. Ithaca; London: Cornell university press. 480 p.

Ershov S. (1898). Materialy dlya sanitarnoy statistiki Sviyazhskogo uezda: Opyt sravnitel'noy demografii russkoy i tatarskoy narodnostey [Materials for sanitary statistics of Sviyazhsk uyezd : the comparative demography of the Russian and Tatar peoples]. Saint Petersburg: Tipografiya Yablonskogo i Perott. 197 p.

Farnsworth B. (1992). Rural women and the law: divorce and property rights in the 1920's, beatrice // Russian peasant women / B. Farnsworth, L. Viola, eds. New York: Oxford university press: $167-188$.

Favr V.V. (1910). K voprosu o polovykh snosheniyakh, o venericheskikh boleznyakh i onanizme uchashcheysya molodezhi: rezul'taty khar'kovskoy ankety sredi studentov [To the question about sexual intercourse, sexually transmitted diseases and masturbation students: results of questionnaire Kharkiv among students]. Kharkov: Tipografiya «Pechatnoe delo»: 1-19.

Fedorov V.A. (1994). Mat' i ditya v russkoy derevne (konets XIX-nachalo XX v.) [Mother and child in the Russian village (the end of XIXth-beginning of XXth centuries)] // Vestnik Moskovskogo universiteta [The Moscow University Herald]. Seriay 8: Istoriya [Series 8: History]. 4: 3-21.

Fenomenov M.Ja. (1925). Sovremennaya derevnya: Opyt kraevedcheskogo obsledovaniya odnoy derevni (derevnya Gadyshi, Valdayskogo uezda, Novgorodskoy gubernii) [The modern village: the experience of the regional survey of one village (village Hadisi, Valdai uyezd, Novgorod province)]. 2. [Moscow; Leningrad: Gosudarstvennoe izdatel'stvo. 211 p.

Freeze G.L. (1990). Bringing order to the Russian family: marriage and divorce in Imperial Russia, 1760-1860 // The journal of modern history. 62 (4): 709-746.

Freeze G.L. (2006). Matrimonial sacrament and profane stories: class, gender, confession, and the politics of divorce in late Imperial Russia // Sacred stories: religion and spirituality in modern Russia / M. Steinberg, H. Coleman, eds. Bloomington, Indiana: Indiana university press: 146-178.

Friz G. (2009). Mirskie narrativy. o svyashchennom tainstve: brak i razvod v pozdneimperskoy Rossii [Worldly narratives. about the Holy sacrament: marriage and divorce in late Imperial Russia] // Pravoslavie: Konfessiya, instituty, religioznost' (XVII-XX vv.) [Orthodox: Confession, institutions, religiosity (XVII-XX centuries)]. Sbornik statey [A collection of articles] / M. Dolbilov, P. Rogoznyy, eds. Saint Petersburg: Izdatel'stvo Evropeyskogo universiteta v Sankt-Peterburge: 122-175.

Gernet M.N. (1911). Detoubiystvo: sotsiologicheskoe i sravnitel'no-yuridicheskoe issledovanie [Infanticide: a sociological and comparative legal research]. Moscow: Tipografiya Imperatorskogo Moskovskogo universiteta. 318 p.

Gernet M.N. (1916). Istreblenie ploda s ugolovno-sotsiologicheskoy tochki zreniya [The extermination of the fetus with the criminal-sociological point of view] // Otchet X obshchego sobraniya Russkoy gruppy Mezhdunarodnogo soyuza kriminalistov 13-16 fevralya 1914 g. v Peterburge [Report X General meeting of the Russian group of the International Union of criminalists 13-16 Feb 1914 in St. Petersburg]. Petrograd: 233-277. 
Giljarovsky F.V. (1866). Issledovanie o rozhdenii i smertnosti detey v Novgorodskoy gubernii [A study on birth and mortality of children in the Novgorod province]. Saint Petersburg: Tipografiya K. Vul'fa. 664 p.

Golod S.I. (1996). XX vek i tendentsii seksual'nykh otnosheniy v Rossii [The twentieth century and trends in sexual relations in Russia]. Saint Petersburg: Aleteyya. 191 p.

Goroda Rossii v 1910 godu [Cities of Russia in 1910] (1914). Saint Petersburg: Tipografiya N.L. Nurkina. 1200 p.

Hajnal J. (1965). European marriage patterns in perspective // Population in history / D.D. Glass, D.E.C. Eversley, eds. London: Edward Arnold publishers: 101-143.

Hanykov Ja.V. (1851). Ocherk istorii meditsinskoy politsii v Rossii [Essay on the history of medical care in Russia]. Saint Petersburg: Tipografiya Ministerstva vnutrennikh del. 114 p.

Hlopin G., I. Jerisman (1899). Meditsina i narodnoe zdravie [Medicine and people's health] // Entsiklopedicheskiy slovar' [Encyclopedic dictionary] / F.A. Brokgauz, I.A. Efron, eds. 27-a: Rossiya [Russia]. Saint Petersburg: Tipografiya Aktsionernogo obshchestva «Izdatel'skoe delo»: 214-227.

Istoriko-statisticheskie tablitsy po Yaroslavskoy gubernii za 1862-1898 gg. [Historical and statistical tables on the Yaroslavl province for 1862-1898] (1901). Yaroslav: Tipografiya Gubernskoy zemskoy upravy. 87 p.

Ivanicky N. (1898). Sol'vychegodskiy krest'yanin, obstanovka ego zhizni i deyatel'nost' [Solvychegodsk peasant, the setting of his life and activities] // Zhivaya starina [Living antiquity]. 1 (8): 3-74.

Ivanilova E.P. (2002). Problema sushchestvovaniya grazhdanskikh brakov v Tambovskoy gubernii, XIX v. [The problem of the existence of civil marriages in the Tambov province, XIX century] // Sotsial'naya istoriya rossiyskoy provintsii v kontekste modernizatsii agrarnogo obshchestva v XVII-XX vv. [Social history of the Russian province in the context of modernization of agrarian society in the XVII-XX centuries]. Materialy mezhdunar. konf., may [Materials of Intern. conf., may] / V.V. Kanishhev, ed. Tambov: Izdatel'stvo TGU: $127-129$.

Jakovlev Ja. (1923). Derevnya kak ona est' [The village as it is]. Moscow: Krasnaya nov'. 132 p.

Jakovlev Ja. (1924). Nasha derevnya: Novoe v starom i staroe v novom [Our village : the New in the old and the old in the new]. Moscow: Krasnaya nov'. 180 p.

Jukina I.I. (2007). Russkiy feminizm kak vyzov sovremennosti [Russian feminism as a challenge of modernity]. Saint Petersburg: Aleteyya Istoricheskaya kniga. 539 p.

Karahanov M.K. (1977). Demograficheskie protsessy v Sredney Azii vo vtoroy polovine XIX stoletiya [Demographic processes in Central Asia in the second half of the nineteenth century] // Brachnost', rozhdaemost', smertnost' v Rossii i v SSSR [Marriages, births and deaths in Russia and in the USSR] / A.G. Vishnevsky, ed. Moscow: Statistika: 191-213.

Kechedzhi-Shapovalov M.V. (1902). Zhenskoe dvizhenie v Rossii i za granitsey [The women's movement in Russia and abroad]. Saint Petersburg: Tipografiya E. Evdokimova. 210 p.

Kon I.S. (1990). Vvedenie v seksologiyu [Introduction to sexology]. Moscow: Meditsina. 336 p.

Kon I.S. (1997). Seksual'naya kul'tura v Rossii: Klubnichka na berezke [Sexual culture in Russia: Strawberry on the birch]. Moscow: O.G.I. 460 p.

Kotlova T.B. (2002). Zamuzhestvo i razvod v zhizni gorozhanki na rubezhe XIX-XX vv. (po materialam tsentral'nykh guberniy Rossii) [Marriage and divorce in the life of urban women 
at the turn of XIX - XX centuries (on materials of the Central provinces of Russia)] // Adam i Eva [Adam and Eve]. 3: 154-172.

Kradeckaja S.V. (2012). Grazhdanskaya identichnost' feministok v Rossii v nachale XX v.: diss. ... kand. ist. nauk. [Civil identity of feminists in Russia in the early XX century: autoabstract Ph.D]. Moscow.

Krjukova S.S. (1992). Brachnye traditsii yuzhnorusskikh guberniy vo II pol. XIX v. [Marriage customs of the southern Russian provinces in the second half of the XIXth century.] // Etnograficheskoe obozrenie [The ethnographic review]. 4: 41-50.

Kulisher E.M. (1916). Nakazuemost' aborta [The punishment for abortion]. Otchet X obshchego sobraniya Russkoy gruppy Mezhdunarodnogo soyuza kriminalistov 13-16 fevralya $1914 \mathrm{~g}$. v Peterburge [Report X General meeting of the Russian group of the International Union of criminalists 13-16 Feb 1914 in St. Petersburg]. Petrograd: 245-255.

Laptev M. (1861). Kazanskaya guberniya [Kazan province]. Saint Petersburg: Voennaya tipografiya. $616 \mathrm{p}$.

Latkin V.N. (1909). Uchebnik istorii russkogo prava perioda imperii: (XVIII i XIX st.) [The textbook of history of Russian law of the period of the Empire: (XVIII and XIX centuries)]. Saint Petersburg: Tipografiya Montvida. 644 p.

Lebina N. (2007). «Navstrechu mnogochislennym zayavleniyam trudyashchikhsya zhenshchin...»: Abortnaya politika kak zerkalo sovetskoy sotsial'noy zaboty // Sovetskaya sotsial'naya politika 1920-kh-1930-kh godov: ideologiya i povsednevnost' ["To meet the numerous allegations of women workers...": Abortion policy as a mirror of Soviet social care // Soviet social policy 1920s-1930s: ideology and everyday life] / P. Romanov, E. Yarskaya-Smirnova, eds. Moscow: Variant: 228-241.

Leshhenko V.Ju. (2004). Russkaya sem'ya (XI-XIX vv.) [Russian family (XI-XIX c.]. Saint Petersburg: SPGUTD. 607 p.

Lipinsky A.I. (1868). Simbirskaya guberniya [Simbirsk governorate]. V 2 chastyakh [In 2 parts]. 2. Saint Petersburg: Voennaya tipografiya. 761 p.

Livi Bachchi M. (2010). Demograficheskaya istoriya Evropy [The demographic history of Europe]. Saint Petersburg: Alexandria. 298 p.

Lukanin A. (1878). Naselenie Okhanskogo uezda Permskoy gubernii po sosloviyam, vozrastam i semeynomu sostavu [The population of Okhansk district of the Perm province on the estates, ages, and family composition] // Zapiski Russkogo geograficheskogo obshchestva po otdeleniyu statistiki [Note RGS, Department of statistics]. 5. Saint Petersburg: Tipografiya V. Kirshbauma.

Maksimova T.O. (1998). Razvod po-russki [Divorce in Russian] // Rodina [Homeland]. 9: 5560.

Marchenko O.V. (1977). Indeksy rozhdaemosti po 50 guberniyam Evropeyskoy Rossii v kontse XIX v. [Indices of fertility for 50 provinces of European Russia in the late nineteenth century] // Brachnost', rozhdaemost', smertnost' v Rossii i v SSSR [Marriages, births and deaths in Russia and in the USSR] / A.G. Vishnevsky, ed. Moscow: Statistika: 128-137.

Mareeva E.P. (2001). Muzhchiny i zhenshchiny pri zaklyuchenii i rastorzhenii braka v XIX v. (po materialam Tambovskoy eparkhii) [Men and women in the conclusion and dissolution of marriage in the XIXth century (on materials of Tambov diocese)] // Ot muzhskikh i zhenskikh k gendernym issledovaniyam [From men's and women's gender studies]. Materialy 
mezhdunar. nauch. konf., 20 aprelya [Proceedings of the international. scientific. Conf., 20 Apr.] / P.P. Shherbinin, ed. Tambov: Izdatel'stvo TGU: 38-42.

Mareeva E.P. (2003). Problema polucheniya zhenshchinami prava na otdel'noe ot supruga prozhivanie (na materialakh Tambovskoy gubernii, XIX -nachalo XX v.) [The problem of obtaining women's right to separate from a spouse stay (on the materials of Tambov province of XIX-beginning of XX century)] // Zhenskaya povsednevnost' v Rossii v XVIII-XX vv. [Women's everyday life in Russia in XVIII-XX centuries]. Materialy mezhdunarodnoy nauchnoy konferentsii, 25 sentyabrya [Materials of the international scientific conference, 25 sept.] / P.P. Shherbinin, ed. Tambov: Izdatel'stvo TGU: 33-37.

Materialy po izucheniyu detskoy smertnosti v Saratovskoy gubernii s 1902 po 1904 g. [Materials for the study of child mortality in Saratov province in 1902 - 1904] (1908). V 3 vyp. [In 3 parts]. 2 / N.I. Tezjakov, comp. Saratov: Saratovskoe gubernskoe zemstvo. 285 p.

McLaren A. (1990). A history of contraception from antiquity to the present. Oxford, UK ; Cambridge, Mass., USA: B. Blackwell. 275 p.

Mel'cin M. O. (1999). Sud'by starinnogo rossiyskogo dvoryanstva v kontse XVIII-nachale XX veka: Knyaz'ya Dolgorukovy v sisteme obshchestvennykh otnosheniy: diss. ... kand. ist. nauk [The fate of the old Russian nobility in the late XVIII-early XX century: Princes Dolgorukovs in the system of social relations: autoabstract Ph.D]. Saint Petersburg.

Mihajlov V.M. (1895). Srednie russkie akusherskie itogi za pyat'desyat let po materialam pechatnykh otchetov rodovspomogatel'nykh uchrezhdeniy, 1840-1890 [The average Russian obstetric outcome in fifty years on materials printed reports of maternity services, 1840-1890]. Novgorod: Tipografiya I.I. Ignatovskogo. 448 p.

Miljutin V. (1946). Izbrannye proizvedeniya [Selected works]. Moscow: Gosudarstvennoe izdatel'stvo politicheskoy literatury. $448 \mathrm{p}$.

Minh A.H. (1890). Narodnye obychai, sueveriya, predrassudki i obryady krest'yan Saratovskoy gubernii [Folk customs, superstitions, prejudices and rituals of the peasants Saratov province]. Saint Petersburg: Tipografiya V. Bezobrazova i K .152 p.

Mironov B.N. (1990). Russkiy gorod v 1740 - 1860-e gody: Demograficheskoe, sotsial'noe i ekonomicheskoe razvitie [Russian city in the 1740-1860 years: Demographic, social and economic development]. Leningrad: Nauka. 271 p.

Mironov B.N. (1991). Istoriya v tsifrakh [History in numbers]. Leningrad: Nauka. 165 p.

Mironov B.N. (2012). Blagosostoyanie naseleniya i revolyutsii v imperskoy Rossii, XVIIInachalo XX veka [The welfare of the population and revolution in Imperial Russia XVIIIbeginning of XX century]. Moscow: Ves' mir. 844 p.

Mironov B.N. (2014). Rossiyskaya imperiya: ot traditsii k modernu: v 3 t. [The Russian Empire: from tradition to modernity: in 3 vol]. 1. Saint Petersburg: Dmitrij Bulanin. 896 p.

Mironov B.N. (2015). Rossiyskaya imperiya: ot traditsii k modernu: v 3 t. [The Russian Empire: from tradition to modernity: in 3 vol]. 3. Saint Petersburg: Dmitrij Bulanin. 992 p.

Moiseenko T.L. (1984). Metody izucheniya vnutrisemeynogo kontrolya nad rozhdaemost'yu : (obzor) [Methods of study of family control of fertility (review)] // Demografiya zapadnoevropeyskogo Srednevekov'ya v sovremennoy zarubezhnoy istoriografii : K XVI Mezhdunar. kongressu ist. nauk (Shtutgart, 1985) [Demography of Western European middle Ages in modern foreign historiography: To the XVI International Congress East. Sciences (Stuttgart, 1985)]. Referativnyy sbornik [Abstract collection]. Moscow: INION: 73-86. 
Muhina Z.Z. (2012). Plodoizgnanie i kontratseptsiya v traditsionnoy krest'yanskoy kul'ture Evropeyskoy Rossii (vtoraya polovina XIX-30-e gg. XX v.) [Podozvanije and contraception in traditional peasant culture of European Russia (second half XIX-30th of XX century)] // Etnograficheskoe obozrenie [Ethnographic review]. 3: 147-160.

Nikologorsky S.A. (2012). Semeynyy vopros v rossiyskoy publitsistike kontsa XIX — nachala XX veka: avtoref. ... kand. ist. nauk [Family question in the Russian journalism of the late XIX — early XX century: autoabstract Ph.D.]. Moscow: Moskovskiy gosuarstvennyy universitet im. M.V. Lomonosova. 30 p.

Novikova N. (2000). Liberal'nyy feminizm v Rossii i na Zapade: opyt sravnitel'nogo analiza [Liberal feminism in Russia and the West: a comparative analysis]. URL: www.kennan.yar.ru/seminars/novikova-24102000.html (accessed: 01.10.2017).

Novosel'skij S.A. (1916a). Obzor glavneyshikh dannykh po demografii i sanitarnoy statistike Rossii [Overview of the most important data on the demographic and health statistics in Russia] // Kalendar' dlya vrachey vsekh vedomstv na 1916 god: v 2 ch. [Calendar for physicians of all departments in 1916: in 2 vol]. 2. Saint Petersburg: K.L. Riker: 14-93.

Novosel'skij S.A. (1916b). Smertnost' i prodolzhitel'nost' zhizni v Rossii [Mortality and life expectancy in Russia]. Petrograd: Tipografiya Ministerstva vnutrennikh del. 208 p.

Novosel'skij S.A. (1978). Demografiya i statistika: izbrannye proizvedeniya [Demographics and statistics: Selected works]. Moscow: Statistika. 269 p.

Novosel'sky S.A. (1914). K voprosu o ponizhenii smertnosti i rozhdaemosti v Rossii [The question of the reduction of mortality and fertility in Russia]. Saint Petersburg: Tipografiya MVD. 16 p.

O sostave i dvizhenii naseleniya po guberniyam Nizhegorodskoy i Yaroslavskoy [On the composition and movement of population in the provinces of Nizhny Novgorod and Yaroslavl] (1861). Saint Petersburg: Tipografiya S.N. Bekeneva. 105 p.

Obshchiy svod po imperii rezul'tatov razrabotki dannykh Pervoy vseobshchey perepisi naseleniya, proizvedennoy 28 yanvarya $1897 \mathrm{~g}$. [General set on the Empire of the results of the development data of the First General census of the population produced 28 January 1897] (1905). V 2 t. [In 2 vol.] / N.A. Trojnicky, ed. Saint Petersburg: N.L. Nyrkin.

Otchet Ministerstva yustitsii za 1834-1840 god [The report of the Ministry of justice for [1834-1840] (1835-1841). Saint Petersburg: Tipografiya Pravitel'stvuiushchego Senata.

Otchet X obshchego sobraniya Russkoy gruppy Mezhdunarodnogo soyuza kriminalistov 13-16 fevralya 1914 g. v Peterburge [Report X General meeting of the Russian group of the International Union of criminalists 13-16 Feb 1914 in St. Petersburg] (1916). Petrograd. $400 \mathrm{p}$.

Pamjatnaja knizhka Voronezhskoj gubernii na 1861 god [The memorable book of the Voronezh province in 1861] (1861). Voronezh: Tipografiya V. Gol'dshtejna. 358 p.

Pamjatnaja knizhka Voronezhskoj gubernii na 1870 - 71 god [The memorable book of the Voronezh province in the year 1870-71] (1871). Voronezh: Tipografiya V. Gol'dshtejna. $346 \mathrm{p}$.

Patterns of first marriage: timing and prevalence (1990). New York: United Nations. 327 p.

Perepis' Moskvy 1902 goda [The census of Moscow 1902] (1904). V 4 vyp. [In 4 parts]. 1. Naselenie. [Population]. 1. Naselenie po polu, vozrastu, mestorozhdeniyu, prodolzhitel'nosti prebyvaniya v Moskve, semeynomu sostoyaniyu, sosloviyam, gramotnosti i stepeni obrazovaniya [Population by sex, age, field, duration of stay in Moscow, marital status, class, 
literacy and level of education]. Mosckow: The statistical Department of the Moscow city Council. $155 \mathrm{p}$.

Petrograd po perepisi naseleniya 15 dekabrya 1910 goda: naselenie [Petrograd census 15 Dec 1910: population] (1915). V 2 ch. [In 2 vol.] / Head of the Department Vladimir Stepanov, ed. 1. Petrograd: Izdanie Gorodskoy upravy po Statisticheskomu otdeleniyu. 339 p.

Pilsudskij B. (1910). Rody, beremennost', vykidyshi, bliznetsy, urody, besplodie i plodovitost' u tuzemtsev ostrova Sakhalina [Childbirth, pregnancy, miscarriage, twins, ugly, infertility and fertility to the natives of the island of Sakhalin] // Zhivaya starina [Living antiquity]. 73-74. I-II: $22-48$.

Popov A.A. (1994). Kratkaya istoriya aborta i demograficheskoy politiki v Rossii [A brief history of abortion and population policy in Russia] // Planirovanie sem'i v Evrope [Family planning in Europe]. 1: 5-7.

Popov G.I. (1903). Russkaya narodno-bytovaya meditsina: Po materialam etnograficheskogo byuro kn. V.N. Tenisheva [Russian folk-domestic medicine : On materials of the ethnographic Bureau book. V.N. Tenisheva]. Saint Petersburg: Tipografiya A.S. Suvorina. $404 \mathrm{p}$.

Poprocky M. (1864). Kaluzhskaya guberniya. V 2 t. [Kaluga province: in 2 vol.]. 1. Saint Petersburg: Tipografiya Je. Vejmara. 706 p.

Preobrazhensky I. (1901). Otechestvennaya tserkov' po statisticheskim dannym s 1840-41 po 1890-91 gg. [The domestic Church according to the statistics from 1840-41 and 1890-91]. Saint Petersburg: Tipografiya E. Evdokimova. 236 p.

Ptuha M. (1928). Smertnost' 11 narodnostey Evropeyskoy Rossii v kontse XIX veka [Mortality 11 Nations in European Russia in the late XIX century]. Kiev: TsSU Ukrainy. 56 p.

Rabinovich M.G. (1978). Ocherki etnografii russkogo feodal'nogo goroda: Gorozhane, ikh obshchestvennyy i domashniy byt [Essays on the Ethnography of the Russian feudal city's Citizens, their public and home life]. Moscow: Nauka. 328 p.

Ransel D. (1982). Problems in measuring illegitimacy in prerevolutionary Russia // Journal of social history Carnegie-Mellon university. 16 (2): 11-27.

Ransel D.L. (1988). Mothers of misery: child abandonment in Russia. Princeton, NJ: Princeton university press. $300 \mathrm{p}$.

Ransel D.L. (2000). Village mothers: three generations of change in Russia and Tataria. Bloomington and Indianapolis: Indiana university press. $314 \mathrm{p}$.

Rashin A.G. (1956). Naselenie Rossii za 100 let (1811-1913 gg.) [The population of Russia for 100 years (1811-1913)]. Statisticheskie ocherki [Statistical essays]. Moscow: Gosstatizdat. $352 \mathrm{p}$.

Riddle J.M. (1997). Eve's herbs: a history of contraception and abortion in the West. Cambridge, Mass.: Harvard university press. 352 p.

Riddle J.M. (2001). Birth, contraception, and abortion // Encyclopedia of European social history from 1350 to 2000. In 6 vols. 2 / P. Stearns, ed. New York: Charles Scribner's Sons: 181191.

Roleder G. (1909). Kak predupredit' beremennost' [How to prevent pregnancy]. Moscow: Tipografiya S.P. Semenova. 87 p.

Rozanov N.P. (2004). Vospominaniya starogo moskvicha [Memories of the old Muscovite]. Moscow: Russkiy mir". 429 p. 
Russkie krest'yane. Zhizn'. Byt. Nravy [The Russian peasants. Life. Gen. Customs] (2004-2017). Materialy «Etnograficheskogo byuro» knyazya V.N. Tenisheva [Materials of «The Ethnographic Bureau» of the Prince V.N. Tenishev]. 1. Kostromskaya i Tverskaya gubernii [Kostroma and Tver provinces]. 2. Yaroslavskaya guberniya [Yaroslavl province]. 3. Kaluzhskaya guberniya [Kaluga province]. 4. Nizhegorodskaya guberniya [Nizhny Novgorod province]. 5. Vologodskaya guberniya [Vologda province]. 6. Kurskaya, Moskovskaya, Olonetskaya, Pskovskaya, Sankt-Peterburgskaya i Tul'skaya gubernii [Kursk, Moscow, Olonets, Pskov, St. Petersburg and Tula province]. 7. Novgorodskaya guberniya [Novgorod province]. 9. Kazanskaya guberniya. Spasskiy i Laishevskiy uezdy [Kazan province. Laishevsky and Spassky districts]. Saint Petersburg: Delovaya poligrafiya.

Sadvokasova E.A. (1969). Sotsial'no-gigienicheskie aspekty regulirovaniya razmerov sem'i [Socio-hygienic aspects of family planning]. Moscow: Meditsina. $191 \mathrm{p}$.

Sankt-Peterburg (1868). Sankt-Peterburg: issledniya po istorii, topografii i statistike stolitsy [Sankt-Peterburg: A study of the history, topography, and statistics of the capital]. V 3 t. [In 3 vol.]. 3. 1. Saint Petersburg: Tipografiya V. Bezobrazova. 207 p.

Sbornik statistiko-ekonomicheskikh svedeniy po sel'skomu khozyaystvu Rossii i inostrannykh gosudarstv [Collection of statistical and economic information on agriculture of Russia and foreign States] (1917). God devyatyy [Ninth year]. Petrograd: Tipografiya I.F. Vaysberga. $649 \mathrm{p}$.

Sbornik svedeniy po Rossii za 1884-1885 gg. [Collection of information on Russia in 18841885] (1887). Saint Petersburg: Tsentral'nyy statisticheskiy komitet Ministersva vnutrennikh del. $295 \mathrm{p}$.

Semenov Ju.I. (1996). Perezhitki pervobytnykh form otnosheniya polov v obychayakh russkikh krest'yan XIX-nachala XX v. [Vestiges of the primitive forms of gender relations in the customs of the Russian peasants of XIX-beginning of XX century] // Etnograficheskoe obozrenie [The ethnographic review]. 1: 39-46.

Semenova-Tjan-Shanskaja O.P. (1914). Zhizn' «Ivana»: ocherki iz byta krest'yan odnoy iz chernozemnykh guberniy [The life of "Ivan": essays from the life of the peasants of the black earth provinces]. Saint Petersburg: Tipografiya M.M. Stasyulevicha. 135 p.

Shcherbinin P.P. (2002). Nezakonnorozhdennye deti v sem'yakh soldatok v XVIII-XIX vv. [Illegitimate children in the families of the wives of soldiers in the XVIII-XIX centuries] // Sotsial'naya istoriya rossiyskoy provintsii v kontekste modernizatsii agrarnogo obshchestva $\mathrm{v}$ XVII-XX vv. [Social history of the Russian province in the context of modernization of agrarian society in the XVII-XX centuries]. Materialy mezhdunarodnoy konferentsii (may 2002) [Materials of international conference (May 2002)] / V.V. Kanischev, ed. Tambov: Izdatel'stvo TGU: 142-146.

Shcherbinin P.P. (2004). Voennyy faktor v povsednevnoy zhizni russkoy zhenshchiny v XVIIInachale XX v. [The military factor in the daily life of Russian women in the XVIII-early XX century]. Tambov: Yulis. 507 p.

Sifman R.I. (1977). Dinamika chislennosti naseleniya Rossii za 1897-1914 gg. [Dynamics of population of Russia in 1897-1914] // Brachnost', rozhdaemost', sem'ya v Rossii i v SSSR [Marriages, births and deaths in Russia and in the USSR] / A.G. Vishnevsky, ed. Moscow: Statistika: 62-82.

Sinkevich G.P. (1929). Vologodskaya krest'yanka i ee rebenok [The Vologda peasant and her child]. Moscow; Leningrad: Gosudarstvenoe meditsinskoe izdatel'stvo. 90 p. 
Stajts R. (2004). Zhenskoe osvoboditel'noe dvizhenie v Rossii: Feminizm, nigilizm i bol'shevizm, 1860-1930 [The women's liberation movement in Russia: Feminism, nihilism and Bolshevism, 1860-1930]. Moscow: Rosspen. 616 p.

Stal' N.E (1867). Penzenskaya guberniya [Penza province]. V 2 ch. [In 2 vol.]. 2. Saint Petersburg: Tipografiya Burgelya. 469 p.

Statisticheskiy ezhegodnik Rossii 1914 g. [Statistical Yearbook of Russia 1914] (1915). II. Petrograd: Tipografiya Shtaba Petrogradskogo voennogo okruga. 119 p.

Statisticheskiy ezhegodnik Rossii 1915 g. [Statistical Yearbook of Russia 1915] (1916). II. Petrograd: CSK. 58 p.

Statisticheskiy ezhegodnik Rossii 1916 g. [Statistical Yearbook of Russia 1916] (1918). 1. Moscow: Tipografiya Moskovskogo Soveta rabochikh, soldatskikh i krest'yanskikh deputatov. $90 \mathrm{p}$.

Statisticheskiy ezhegodnik S.-Peterburga za 1901-1902 gg. [Statistical Yearbook of St. Petersburg for 1901-1902] (1905). Saint Petersburg: S.-Peterburgskaya gorodskaya tipografiya. $761 \mathrm{p}$.

Stites R. (1991). The women's liberation movement in Russia: feminism, nihilism, and bolshevism, 1860-1930. Princeton: Princeton university press. 464 p.

Svod statisticheskikh svedeniy po delam ugolovnym proizvedennym v 1873, 1892, 1913 godu [A set of statistical information on criminal cases made in 1873, 1892, 1913 year] (1875, 1896, 1916). Saint Petersburg: Ministerstvo yustitsii.

Svod zakonov Rossiyskoy imperii [The laws of the Russian Empire] (1857). X. 1. Zakony grazhdanskie [The civil laws].. Saint Petersburg: Vtoroe otdelenie sobstvennoy ego imperatorskogo velichestva kantselyarii. 491, 104 p.

Tihonov V.P. (1891). Materialy dlya izucheniya obychnogo prava sredi krest'yan Sarapul'skogo uezda Vyatskoy gubernii [Materials for the study of customary law among the peasants Sarapul district of the Vyatka province] // Sbornik svedeniy dlya izucheniya byta krest'yanskogo naseleniya Rossii [Collection of information for the study of life of the peasant population of Russia]. 3. / N. Haruzin, ed. Moscow: Tipografiya A. Levenson i K. $146 \mathrm{p}$.

Tishkin G.A. (1995). Zhenskiy vopros v istorii Rossii [The question of women in the history of Russia] // Feminizm i rossiyskaya kul'tura [Russian Feminism and culture] / G.A. Tishkin, ed. Saint Petersburg: SPbGAK: 138-167.

Tolts M.S. (1977). Brachnost' naseleniya Rossii v kontse XIX-nachale XX v. [Marriages of the population of Russia in the late XIX-early XX century] // Brachnost', rozhdaemost', smertnost' v Rossii i v SSSR [Marriages, births and deaths in Russia and in the USSR] / A.G. Vishnevsky, ed. Moscow: Statistika: 138-153.

Tomilin S.A. (1987). K voprosu o plodovitosti krest'yanki i vliyanii ee na detskuyu smertnost' [To the question of peasant fertility and its effect on child mortality] // Sovetskaya demografiya za 70 let [Soviet demography in 70 years] / T.V. Rjabushkin, ed. Moscow: Nauka: 107-109.

Tretiy s"ezd Obshchestva russkikh vrachey v pamyat' N.I. Pirogova v S.-Peterburge (3-10 yanvarya 1889 g.): polnyy otchet [The third Congress of the Society of Russian physicians in memory of N.I. Pirogov, St. Petersburg (3-10 January 1889): full report] (1889). Saint Petersburg. $441 \mathrm{p}$. 
Trubnikov V.V. (1858). Rezul'taty narodnykh perepisey v Ardatovskom uezde Simbirskoy gubernii [The results of the national census in the Ardatov district of the Simbirsk province] // Sbornik statisticheskikh svedeniy o Rossii, izdavaemyy RGO [Collection of statistical information on Russia, published by RGS]. 3. Saint Petersburg: Tipografiya Morskogo ministerstva: 343-427.

Uspensky G.I. (1954). Polnoe sobranie sochineniy [Complete works]. V 14 t. [In 14 vol.]. 8. Moscow: Izdatel'stvo Akademii nauk SSSR. 647 p.

Van-der-Born R. (1909). Izbezhanie materinstva v svyazi s gigienoy braka, s tochki zreniya sovremennoy meditsiny [The avoidance of maternity in connection with the hygiene of marriage, from the point of view of modern medicine]. Saint Petersburg: Tipografiya tovarishchestva «Gramotnost'». $144 \mathrm{p}$.

Veremenko V.A. (2007). Dvoryanskaya sem'ya i gosudarstvennaya politika Rossii (vtoraya polovina XIX - XX v.) [Noble family and the state policy of Russia (second half XIX $-\mathrm{XX}$ century)]. Saint Petersburg: Evropeyskiy dom. 622 p.

Vigdorchik N.A. (1914). Detskaya smertnost' sredi peterburgskikh rabochikh [The infant mortality rate among the St. Petersburg workers] // Obshchestvennyy vrach [Public doctor]. 2: 212-253.

Vishnevsky A.G. (1977). Rannie etapy stanovleniya novogo tipa rozhdaemosti v Rossii [Early stages of formation of a new type of fertility in Russia] // Brachnost', rozhdaemost', smertnost' v Rossii i v SSSR [Marriages, births and deaths in Russia and in the USSR] / A.G. Vishnevsky, ed. Moscow: Statistika: 105-135.

Vishnevsky A.G. (2005). Demograficheskaya revolyutsiya [The demographic revolution] // Vishnevskij A.G. Izbrannye demograficheskie trudy [Selected demographic works]. Moscow: Nauka. 1: 5-216.

Vishnevsky A.G., M.S. Tolts (1988). Evolyutsiya brachnosti i rozhdaemosti v sovetskiy period [The evolution of nuptiality and fertility in the Soviet period] // Naselenie SSSR za 70 let [The population of the USSR for 70 years] / L.L. Rybakovsky, ed. Moscow: Nauka: 75-114.

Vladimirsky-Budanov M. F. (1900). Obzor is $\neg$ torii russkogo prava [An overview of the history of Russian law]. Kiev; Saint Petersburg: N.Ya. Golobin. 674 p.

Voenno-statisticheskiy sbornik [Military statistical compilation] (1871). 4. Rossiya [Russia]. 1. I N.N. Obruchev, ed. Saint Petersburg: Voennaya tipografiya. 922 p.

Vojcehovsky A.I. (1888). Ob odnom narodnom abortivnom sredstve [About one people's abortive means] // Protokoly i trudy obshchestva elisavetgradskikh vrachey za 1886-1887 gg. [Minutes and papers of the society Elisavetgrad doctors for 1886-1887.] Saint Petersburg: 37-41.

Vosproizvodstvo naseleniya SSSR [The reproduction of the population of the USSR] (1983) / A.G. Vishnevsky, A.G. Volkov, eds. Moscow: Finansy i statistika. 303 p.

Vsepoddanneyshiy otchet ober-prokurora Svyateyshego Sinoda po vedomstvu pravoslavnogo ispovedaniya za 1842-1914 god [Report of the chief Procurator of the Holy Synod on Department of Orthodox confession for 1842-1914] (1842-1914). Saint Petersburg: Sinodal'naya tipografiya.

Vsepoddanneyshiy otchet ober-prokurora Svyateyshego Sinoda po vedomstvu pravoslavnogo ispovedaniya za 1913, 1914 god [Report, Procurator of the Holy Synod on Department of Orthodox confession for 1913, 1914] (1915). Saint Petersburg: Sinodal'naya tipografiya. $142 \mathrm{p}$. 
Zabolotnaja L.P. (2010). Imeli li zhenshchiny pravo na razvod v Moldove XVI-XVII vv.?

[Whether women have had the right to divorce in Moldova of XVI-XVIIth centuries?] //

Sotsial'naya istoriya. Ezhegodnik 2009 [Social history. Yearbook 2009]. Moscow: Aleteyya: 9-22.

Zakharov S.V. (2002). Rozhdaemost' v Rossii: pervyy i vtoroy demograficheskiy perekhod [The birth rate in Russia: first and second demographic transition] // Demograficheskaja modernizacija, chastnaja zhizn' i identichnost' v Rossii [Demographic modernization, private life and identity in Russia]. Tezisy dokladov [Abstracts]. Nauchnaya konferentsiya [A scientific conference]. Moskva, 27-28 fevralya [Moscow, February 27-28]. Moscow: TsDECh INP RAN, Institut etnologii i antropologii RAN: 19-26.

Zakharov S.V. (2003). Demograficheskiy perekhod i vosproizvodstvo pokoleniy v Rossii [Demographic transition and the replacement of generations in Russia] // Voprosy statistiki [Questions of statistics]. 11:3-12.

Zhbankov D.N. (1922). O polovoy zhizni uchashchikhsya zhenshchin [On the sexual life of female students] // Vrachebnoe delo [Medical Practice]. 10/12. 